\title{
LA HERMANDAD EN GALICIA. 1490-1498
}

\author{
MIGUEL-ÁNGEL LADERO QUESADA
}

\begin{abstract}
Resumen
Estudio y edición de las cuentas de la Hermandad en Galicia bajo los Reyes Católicos, conservadas en el Archivo General de Simancas. En el estudio preliminar se explica el significado de los conceptos del gasto, las formas de cobro, y el personal encargado de la administración de los recursos. La edicion de las cuentas se ofrece en formato reducido, con índices de personas y lugares.
\end{abstract}

\section{Palabras Clave}

Hermandad, Reyes Católicos, Galicia, cuentas, gastos militares.

\section{Abstract}

Study and edition of 'Hermandad' accounts in the Kingdom of Galicia under the 'Catholic Kings' rule, conserved at the Simancas Archive. In the first part (study) the author explains the different expenses, collections and the staff charged on the administration of the revenues. The accounts data are edited in a quick form with a people and places index.

\section{Key Words}

Hermandad, Catholic Kings, Kingdom of Galicia, accounts, military expenses. 


\section{ALGUNOS DATOS PREVIOS}

Se ha considerado con buen fundamento que, tanto en Castilla como en Galicia, las hermandades de 1467 fueron el preludio de la organizada por los Reyes Católicos a partir de 1476 aunque hemos de señalar una diferencia notable en los medios y en los objetivos, especialmente en Galicia, porque, en el primer caso, los irmandiños protagonizaron una insurrección antiseñorial, aunque lo hicieran en nombre de un rey lejano e inoperante, mientras que en el segundo el poder real actuó directamente, aunque aplicara «métodos de excepción» en los primeros años ochenta para pacificar la tierra y extirpar abusos o rebeldías nobiliarias, pero el objetivo era instalar una administración eficaz de la justicia y la fiscalidad regias y restaurar el normal funcionamiento del orden social estamental y, en su seno, el del régimen señorial ${ }^{1}$.

Los partidarios de Isabel y Fernando en Galicia, con el arzobispo de Santiago, Alfonso de Fonseca, a la cabeza, dominaron la situación en buena parte del reino desde 1475 durante unos años en los que los primeros gobernadores reales -don Enrique Enríquez, conde de Alba de Liste, primero, don Pedro de Villandrando, conde de Ribadeo, después- apenas tuvieron poderes efectivos como tales. Así, mientras en otras regiones de la corona castellana se implantaba la Hermandad a partir de 1476, en Galicia y algunas otras tardó más en ocurrir tal acontecimiento ${ }^{2}$.

Fue el arzobispo Fonseca, secundado por el conde de Lemos y por Diego de Andrade, quien aceptó la entrada de la Hermandad, pese a la oposición de muchos nobles gallegos, que ofrecieron, en 1477, 500.000 mrs., la entrega en prenda de algunos castillos y la promesa de atender ellos mismos el orden público, si la Hermandad no se instauraba. De todos modos, hasta el final de la guerra contra Portugal no se determinaron los reyes a implantarla en Galicia. Encomendaron la tarea de aplicar allí las leyes dadas en Madrigal a Antonio de Paz, arcediano de Cornoces

${ }^{1}$ BARROS, C., Mentalidad justiciera de los irmandiños, siglo XV, Madrid, 1990, en especial pp. 237-238. BECEIRO, I., La rebelión Irmandiña, Madrid, 1977. Sobre la implantación de la Hermandad y las resistencias señoriales, PARDO, E. J., El mariscal Pedro Pardo de Cela y la Galicia de fines del siglo XV, Lugo, 1981, y Los señores de Galicia: tenentes y condes de Lemos en la Edad Media, La Coruña, 2000, 2v.. GARCÍA ORO, J., Galicia en la Baja Edad Media. Iglesia, señorio y nobleza, Santiago de Compostela, 1977 ( $2{ }^{a}$ ed., La Coruña, 1999) y, Galicia en los siglos XIV y XV, Pontevedra, 1987, 2 v. (volumen primero). También, PORTELA PAZOS, S., Galicia en tiempo de los Fonseca, Madrid, 1957.

${ }^{2}$ Sobre la Hermandad en general, su funcionamiento y sus cuentas desde 1490 , remito a mi artículo en prensa, a publicar en Boletín de la Real Academia de la Historia.

Cuadernos de Estudios Gallegos, Tomo LII, Fascículo 118, Santiago 2005. (Págs. 239 - 287) 
y al licenciado Fernando Gómez de Tordehumos, que fueron enviados a Galicia en febrero de 1480 con aquel propósito ${ }^{3}$.

Las primeras noticias concretas sobre la implantación de la Hermandad en Galicia corresponden, en efecto, a 1480: La Junta de la Hermandad reunida en Madrid, en agosto de aquel año, propuso a los reyes algunas leyes nuevas que éstos promulgaron, para ampliar y mejorar el ordenamiento jurídico de la institución. En una de ellas se alude a la formación de una armada utilizando para ello el dinero o contribución de las Hermandades provinciales integradas en la general, en Galicia, Asturias, Vizcaya, Guipúzcoa, Álava y las tierras costeras de Andalucía:

Otrosy, por quanto al seruiçio de Dyos nuestro Señor e a la ensalçaçion de la santa fe catholica e a nuestro seruiçio e al bien huniversal destos nuestros regnos mucho cunple e conbyene que se faga armada por la mar e porque para esto son nesçesarios muchos gastos e espensas, por ende que desde agora asygnavan e asygnaron para faser la dicha armada e para todas las cosas e gastos a ella nesçesarios toda la contribuçion o ayuda que se ha fecho e fisyere por rason de las dichas Hermandades en el reyno de Galisya e en el prinçipado de Asturias e en el condado de Viscaya e Encartaçiones e provinçias de Guipuscoa e Alaua e a las villas e logares de la costa de la mar e por todos los conçejos e vesynos e presonas syngulares dellos, e las villas de Moguer e Palos e Santa María del Puerto que son en el Andalusya....

Se trataba de la armada que fue enviada meses después a combatir a los turcos en el S. de Italia. Los encargados de formarla, reunir las tripulaciones y recaudar los recursos precisos fueron el contador Alfonso de Quintanilla y el provisor de Villafranca, don Juan de Ortega, «que administraban las cosas de las Hermandades», y lo consiguieron no sin grandes trabajos: de hecho, era el primer paso para la implantación de la Hermandad en aquellas tierras, aunque ignoramos cuál fue la participación gallega efectiva ${ }^{5}$.

\footnotetext{
${ }^{3}$ Cartas reales de 18 y 28 de febrero de 1480, resumidas por GARCÍA ORO, J., op. cit., cap. XI.

${ }^{4}$ SÁNCHEZ BENITO, J. M., Los Reyes Católicos y la Hermandad general (1475-1498), Cuenca, Colegio Universitario, 1988, p. 93-94.

${ }^{5}$ PULGAR, Fernando del, Crónica de los Reyes Católicos, Madrid, 1943, cap. CXIX. Ley del ordenamiento de Hermandad de la Junta de Madrid, c.r. 25 septiembre 1480 en SUÁREZ BILBAO, Fernando, Un cambio institucional en la política interior de los Reyes Católicos: la Hermandad General, Madrid, 1998, doc. 35 (Simancas, Diversos de Castilla, leg. 8, $\mathrm{n}^{\circ} 4$ ). Dos cartas reales de 12 de diciembre de 1480 tratan sobre la implantación de la Hermandad en la Trasmiera y el reparto de «galeotes» entre los lugares de behetría para formar la armada (doc. 36 y 37, Simancas, Registro General del Sello, doc. 51 y 85). En Simancas, Contaduría del Sueldo, primera serie, leg. 53, f. 10
} 
La restauración del poder real efectivo en Galicia había comenzado también por entonces, en octubre de 1480, con el nombramiento y envío de don Fernando de Acuña, hijo del conde de Buendía, como gobernador y justicia mayor, acompañado del licenciado Garci López de Chinchilla, letrado del Consejo Real, como alcalde mayor, con una compañía armada de doscientos o trescientos de caballo. Acuña y Chinchilla restablecieron la justicia y muchos aspectos del gobierno en el año y medio siguiente ${ }^{6}$. Parece que fue a raíz de aquella acción inicial cuando se instauró plenamente la Hermandad en Galicia, en agosto de $1482^{7}$, con el cobro de la correspondiente contribución, aunque comenzara a percibirse con retraso. Por entonces, los municipios propusieron reformas que «buscaban aclimatarla en Galicia, evitando o paliando sus aristas más punzantes»: pidieron que se redujera la contribución, teniendo en cuenta la pobreza del reino, y que los diputados, recaudadores, tesoreros y delegado del consejo de Hermandad en Galicia fueran gallegos, así como los caballeros y escuderos que componían la tropa de 300 «lanzas $)^{8}$.

Los reyes no debieron aceptar aquellas peticiones pero no pasó mucho tiempo sin que sustituyeran al arcediano de Cornoces por un nuevo receptor y tesorero, Álvaro de Gijón, en octubre de 1484, y procedieran a regular el proceso de cobro, en diciembre del mismo año, al dictar un conjunto de disposiciones declarando la forma en que se había de empadronar de nuevo el vecindario gallego para que la contribución se recaudase por padrones de vecinos, y nunca por arrendamiento, por el perjuicio que esto traería a los vecinos. Al mismo tiempo, limitaron la exención de pago a los hidalgos de solar conocido «que tengan privillejo dello», pero no respetaron otros privilegios antiguos de exención de pechos reales, como eran los de los campesinos sujetos a jurisdicción de instituciones eclesiásticas. Para evitar reclamaciones, declararon que la contribución de la Hermandad no era

\footnotetext{
hay un reparto de la contribución de la Hermandad para pagar una armada en 1481, pero no figura la parte a pagar por Álava, Guipúzcoa y Vizcaya, y sobre Galicia se escribe: «hase de saber la contribuçión del reyno de Gallizia».

${ }^{6}$ PULGAR, cap, CXVIII. Sobre la institución del gobernador en la Castilla del siglo XV. Un buen estudio general sobre la implantación de la Gobernación en Galicia en GONZÁLEZ ALONSO, B., Gobernación y gobernadores. Notas sobre la administración de Castilla en el periodo de formación del Estado moderno, Madrid, 1974.

${ }^{7}$ El «año octavo» de la Hermandad de Galicia comienza el 15 de agosto de 1489 (Simancas, C.M.C. primera época, leg. 43).

${ }^{8}$ LÓPEZ FERREIRO, A., Fueros municipales de Santiago y su tierra, Santiago, 1895, II, pp. 310-317, cit. por GARCIA ORO, 1977, op. cit. También, LÓPEZ FERREIRO, A., Galicia en el último tercio del siglo XV, La Coruña, 1896-1897 (reed., Vigo, 1968).
} 
«pecho ni monedas ni tributos que perjudique ni pueda perjudicar a qualesquier previllejos e esençiones e libertades e franquesas e fidalguías», sino «serviçio graçioso que nos fue e es otorgado por los dichos nuestros regnos de su propia voluntad vistas por ellos las neçesydades que se determinaron ... para prosecuçion de los malhechores e seguridad de los caminos e esecuçion de la nuestra justiçia e bien e paz de los dichos nuestros regnos e señoríos ... e para ayuda de la conquista e justa guerra que tenemos e proseguimos contra el rey e moros de Granada enemigos de nuestra santa fe católica»?.

En marzo de 1486, los reyes habían enviado a Galicia a su vasallo y «contino» Juan de Arévalo con el encargo de que revisara los padrones hechos para el cobro de la contribución de la Hermandad, desde su comienzos, para completarlos con quienes hasta entonces no habían sido empadronados. Arévalo tomaría cuentas de todos los años pasados y seguiría como contador hasta nueva orden regia. Averiguaría las deudas dejadas por el anterior tesorero de la Hermandad en Galicia, Álvaro de Gijón, y por otros tesoreros y receptores. Iba a Galicia, además, con potestad para «tomar e asentar qualesquier lanças que cunplan a nuestro serviçio que vivan con Nos de acostamiento en ese dicho reino», es decir, para formar una red de personas especialmente fieles y ligadas a los reyes, y disponía de facultad «para faser qualesquier pesquisas y aver algunas ynformaçiones que Nos le mandamos que faga en ese dicho reyno de Galizia cumplideras a nuestro serviçio e a la esecuçion de la nuestra justiçia ordinaria e de la Hermandad de ese dicho reyno». ${ }^{10}$

Aunque el rey había hecho ya un primer viaje hasta Astorga a comienzos de 1483 para reprimir la rebeldía del conde de Lemos y, después de su muerte, para pacificar la pugna sucesoria entrē su nieto y el conde de Benavente ${ }^{11}$, el primer viaje de Isabel y Fernando a Galicia no ocurrió hasta el otoño de $1486^{12}$. Por entonces hacía dos años que habían nombrado gobernador y justicia mayor de aquel reino a don Diego López de Haro, y «corregidor» al doctor Sancho García del Espinar. López de Haro y Espinar continuaron la obra de sus antecesores pero ya en condiciones de mayor sosiego, y pudieron vencer las últimas resistencias nobiliarias, especialmente la del conde de Lemos, que exigió una acción militar

\footnotetext{
${ }^{9}$ Simancas, Registro General del Sello (R.G.S.), diciembre de 1484, f. 78 a 81 . Publicados por SUÁREZ BILBAO, op. cit., doc. 43 a 46. El nombramiento de Álvaro de Gijón en RGS, octubre 1484, f. 186, según GARCÍA ORO, 1977, op. cit.

${ }^{10}$ SUÁREZ BILBAO, op. cit., doc. 57, de 1486, marzo, 22, Medina del Campo (R.G.S., marzo de 1486, f. 182).

${ }^{11}$ PULGAR, cap. CXLIII.

${ }^{12}$ PULGAR, cap. CXCV.
} 
entre junio y octubre de 1486, centrada en torno al sitio de Sarria, con empleo de tropas procedentes de Castilla, traídas por el gobernador, y otras autóctonas.

Al mismo tiempo, la campaña contra el conde don Rodrigo obligó al gobernador y justicia mayor, don Diego López de Haro a tomar recursos financieros extraordinarios sobre los ingresos de la predicación de indulgencia de cruzada y de los «subsidios» de las diócesis gallegas, lo que demuestra que no había entonces otros medios disponibles, ni siquiera la contribución de la Hermandad. Conocemos el asunto gracias a la cuenta de Juan de Palma, que pagó a la gente de guerra en nombre del tesorero real Ruy López de Toledo. Palma recibió aquella orden regia por cédula de 22 de marzo de 1486, y pagó por nóminas y «libramientos» firmados por el gobernador y por el contador Juan de Arévalo, «seyendo asentadas en los libros de la Hermandad, que tiene en Galizia Juan de Villaverde por el provisor [Juan de Ortega] e Alonso de Quintanilla». Pero los 2.841.477 maravedíes gastados en la operación procedían de los tesoreros de la cruzada en Galicia y de los «subsidios» pagados aquel año por las diócesis, aunque el objetivo declarado de aquellos fondos era la guerra contra Granada ${ }^{13}$. Interesa el detalle del gasto porque pone de manifiesto la precariedad de los medios militares de que disponía López de Haro todavía en aquel momento:

Caballeros y escuderos que vinieron de Castilla. 5 pagos, junio a octubre

Espingarderos y peones del mismo origen. 5 pagos, mayo a noviembre.

Alvar González de Rivadeneira, escuderos y peones. 6 pagos, mayo-octubre ${ }^{14}$

Conde de Altamira, escuderos. 3 pagos, julio-agosto

Conde de Monterrey y Diego de Andrada, escuderos. 1 pago, agosto.

Diego de Andrada, escuderos. 4 pagos, julio-septiembre

Alfonso Vázquez de Cavacos, acostamiento. 1 pago, julio

Fernán Pérez Parragues, escuderos y peones. 1 pago, agosto

Don Juan Pimentel (capitán Alonso de Nava). 1 pago, agosto

Pedro de Páramo, peones. 1 pago, agosto

Don Rodrigo de Moscoso, escuderos y peones. 1 pago, agosto

Peones de La Coruña y Betanzos. 2 pagos, agosto

Escuderos gallegos de acostamiento. 2 pagos, agosto-septiembre 81.880

Canteros, trabuqueros y herreros. 2 pagos, julio-septiembre 29.970

Viaje de Nuño de Valencia a Vizcaya, «por las bombardas y almacén» 3 de septiembre 5.000

${ }^{13}$ Simancas, Contaduría Mayor de Cuentas, primera época, leg. 273.

${ }^{14}$ En mayo tuvo 10 lanzas y 50 peones «sobre Castro de la Peña, cabe Puerto Marín». 
Transporte de pólvora. 18 de mayo

Provisiones consumidas en el real de Sarria

«Cosas de extraordinario» gastadas en el real de Sarria

Pago de la gente de la capitanía ordinaria del gobernador, cuando fueron

al real de Sarria. Pagador, Per Álvarez de la Serna

A escuderos de la capitanía del gobernador. 28 de noviembre.

El cierre de la cuenta no puede ser más simbólico: Los reyes vienen a Galicia y, el seis de octubre, Palma paga a Ruy Acedo, platero de Santiago, 21.280, 5 maravedíes por dos veneras de oro esmaltado, siete bordones y siete «santiagos» que los monarcas iban a utilizar en su condición de peregrinos a Compostela. Las medidas políticas que tomaron durante su viaje, el allegamiento de voluntades y la pacificación contribuyeron a dar un sesgo nuevo y a terminar, entre otras cosas, con las resistencias que se ponían al pago de las contribuciones de la Hermandad, incluyendo las extraordinarias que se cobraron para reclutar y pagar tropas y acémilas de transporte con destino a la guerra de Granada, puesto que se comprueba la presencia de peones gallegos en las campañas siguientes: para la de 1489, por ejemplo, se hizo una leva de 3.000. Y como la misión de Juan de Arévalo no se había podido completar en 1486, los reyes se la encomendaron de nuevo en enero de 1487: Arévalo se convirtió a partir de entonces y durante muchos años en un personaje clave para el buen funcionamiento de la Hermandad en Galicia ${ }^{15}$.

\section{LAS CUENTAS DE LA «QUINTA PRORROGACIÓN». 1490-1493 [1489-1492 EN GALICIA]}

Así, pues, tras el viaje regio a Galicia y la implantación del germen de lo que sería la Audiencia de Galicia, formada por cuatro doctores del Consejo Real, la administración territorial del poder monárquico en el reino se estabilizó definitivamente ${ }^{16}$. Y aquí es donde entra en juego el análisis de las cuentas de la Hermandad, conservadas a partir de 15 de agosto de 1490 hasta que se extingue la contribución

\footnotetext{
${ }^{15}$ Carta real de 1487, enero 29, Salamanca, publicada por FERNÁNDEZ VEGA, L., La Real Audiencia de Galicia. Órgano de gobierno en el Antiguo Régimen, 1480-1808, La Coruña, 1982, 3 v., vol. III, pp. 22-24. La leva de peones para 1489, ordenada por carta real de 1488, octubre 4, Valladolid, en pp. 24-26.

${ }^{16}$ FERNÁNDEZ VEGA, L., La Real Audiencia de Galicia, op. cit.
} 
en agosto de 1498, puesto que su lectura permite conocer con detalle muchos aspectos de su organización y funcionamiento ${ }^{17}$. El resumen detallado de las cuentas se presenta como apéndice de este artículo, de manera que aquí sólo haremos los comentarios generales precisos para entender mejor su contenido, que proporciona numerosos datos y nombres sobre la historia gallega de aquellos años, útiles para otras investigaciones particulares.

Ante todo, se puede suponer que el funcionamiento de la Hermandad en Galicia requirió la reunión más o menos regular de procuradores de municipios de sus cinco «provincias», aunque las cuentas sólo dan noticia de una, celebrada en Lugo, en $1491^{18}$. Estas Juntas serían el precedente inmediato de las Juntas provinciales, a partir de 1500 . Se regirían, como los demás aspectos de funcionamiento de la Hermandad, por las ordenanzas que regían la de Castilla puesto que se trataba de la misma Hermandad, con órganos superiores de dirección comunes, aunque en Galicia tuviera un régimen propio y autónomo dadas las características del país. En ambos casos, el año fiscal de la Hermandad comenzaba el 15 de agosto y las prórrogas de la contribución se establecían por trienios.

La contribución de la Hermandad respondía a los mismos cánones que en el resto de la Corona castellana, pero la singularidad consistía en que, en Galicia, era la principal fuente de ingresos que proveía al mantenimiento del restaurado aparato del poder monárquico, con excepción de los corregidores, que cobraban su salario del municipio correspondiente ${ }^{19}$. Así se expresa claramente en la carta dada a Juan de Arévalo en enero de 1487, donde se le ordena que, junto con el gobernador López de Haro, libre con cargo a dicha contribución,

Los maravedíes de los salarios que oviere de aver el dicho governador e los letrados del dicho nuestro Consejo, así de lo hordinario como de la hermandad, e los otros ofiçiales e personas que en el dicho Reino de Galicia por nuestro mandado agora residen, e de aquí adelante resydieren, con el sueldo de las lanças e peones que están o estovieren en el dicho reino por

\footnotetext{
${ }^{17}$ Las cuentas del trienio 15 agosto 1490 a 15 agosto 1493 (años octavo a décimo), cuando la tesorería general estaba en manos de Luis de Santángel y Francisco Pinelo, en Simancas, Contaduría Mayor de Cuentas, primera época, leg. 134 (duplicadas en leg. 128). Las de los dos trienios siguientes (15 agosto 1493 a 15 agosto 1498), siendo tesorero general Alonso Gutierrez de Madrid, en el leg. 43. En Galicia, la contribución se cobraba con un año de retraso (llevaba «un año recargado»), de modo que los trienios eran 1489-1492, 1492-1495 y 1495-1498, aunque en realidad se cobrara un año después en cada caso, adaptándose al calendario general de la Hermandad, que correspondía a los periodos de arrendamiento trienal antes citados.

${ }^{18}$ Asiento $\mathrm{n}^{\circ} 59$ del apéndice.

${ }^{19}$ Algunos datos en LUNENFELD, M., Los corregidores de Isabel la Católica, Barcelona, 1980, p. 212,213 y 219 .
} 
nuestro mandado, asy con el dicho governador como en las fortalezas en que tenemos puestos alcaydes ... E otrosy para que puedan librar en la dicha contribuçion los marvedies que se deven de los acostamientos que vos, el dicho gobernador, por nuestro mandado asentasteis en el dicho reyno de Galizia fasta en fin del año pasado de ochenta e seys, e para faser las otras cosas que le mandamos...20.

El cargo o importe total de la contribución apenas se modificó en los nueve años que aquí estudiamos: un poco más de seis millones de maravedíes al año, cobrados por los «receptores» del tesorero de la Hermandad General a partir del reparto previsto en los padrones que asignaban una cantidad a cada lugar, de acuerdo con el volumen de su vecindario («encabezamiento»): si hemos de atenernos a lo que dejaban de pagar los vecinos «excusados» por diversos motivos, en el trienio 1490-1493 la contribución era de cuatro reales por vecino y año (124 mrs.). El reparto porcentual entre las cinco «provincias» gallegas de la Hermandad tampoco se modificaría, aunque sólo lo conocemos para ese trienio:

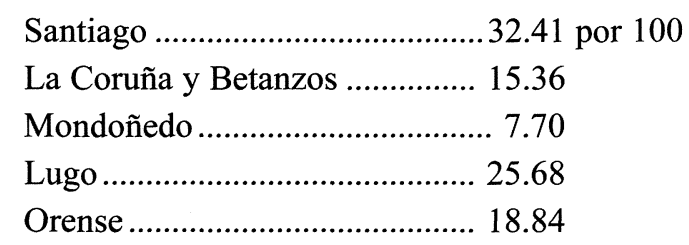

El cobro, por supuesto, nunca era perfecto sino que se admitía a los tesoreros y receptores diversas «suspensiones» $\mathrm{y}$ «descargos» por cantidades dejadas de cobrar y por deudas pendientes. En 1490, como en años anteriores, el dinero se administraba, de acuerdo con las órdenes regias recibidas, por el contador Juan de Arévalo, «contino» de los reyes, que ponía los libramientos a la firma de don Diego López de Haro, capitán, gobernador y justicia mayor de los reyes en Galicia. Intervenían en la gestión también los contadores de la Hermandad en el reino, puesto que eran los que conocían el estado financiero de la institución en cada momento: Pedro Álvarez de la Serna, que era contador lugarteniente por el ya obispo de Almería, don Juan de Ortega, y Gonzalo Moro, contador del sueldo de la «capitanía» de la Hermandad que servía en Galicia, en nombre de Alfonso de Quintanilla. Recordemos que Ortega y Quintanilla eran las cabezas rectoras de la Hermandad en toda Castilla.

${ }^{20}$ FERNÁNDEZ VEGA, L., p. 23. 
Los renglones principales de gasto eran los mismos cada año: salarios, sueldos, tenencias, acostamientos, libranzas, malhechores, salarios y descargos de tesoreros.

Los salarios se refieren a lo que llamaríamos hoy gobernación y justicia civiles mientras que los sueldos atañen a los oficios militares. Había personas que los reunían de uno y otro tipo, como el gobernador López de Haro. Además, las cuentas suelen especificar pagos por periodos de tiempo, a menudo bimestres o tercios de año, y pocas veces dan noticia del salario o sueldo anual. Sin embargo, hay una ordenanza real sobre pagos, de 7 de abril de 1491, que sí lo hace. He aquí el resumen ${ }^{21}$ :

Don Diego López de Haro, salario anual por gobernador 200.000

Doctor Sancho García del Espinar, del consejo real, alcalde mayor de Galicia, 200.000 anuales, que descienden a 150.000 desde 15 de mayo de 1491 , más 70.000 como juez ejecutor de la provincia de Segovia, que descienden a 46.646 196.646

[En 1492 era también alcalde mayor el doctor Luis Niño, maestrescuela de Jaén, que sumó su actividad a la del doctor Sancho García del Espinar]

Licenciado Antonio Cornejo, del consejo real, alcalde mayor de Galicia 120.000

Juan de Arévalo, contador 180.000

Pedro Álvarez de la Serna 50.000

Alonso Alvarez y Francisco de Ávila, escribanos del consejo real, 10.000 cada uno ...... 20.000 Marcos de Navares, ejecutor general de la Hermandad 80.000

Jueces ejecutores de la Hermandad de las provincias de Santiago, La Coruña, Mondoñedo, Luego y Orense, 10.000 a cada uno hasta 15 de mayo y 5.000 en lo sucesivo . 25.000

Respecto a los sueldos, el resumen es éste:

Don Diego López de Haro, salario anual por capitán 200.000

Carlos Enríquez de Cisneros, capitán, para él y para 5 «lanzas dobladas» 106.000

Gonzalo de Moro, «ayuda de costa» además de su «lanza doblada» 10.000

Alférez de la capitanía, además de su «lanza doblada» 7.000

41 «lanzas dobladas» a $23.750 \mathrm{mrs} /$ año, y a 19.870 desde 15 de mayo, como el resto de las «lanzas» de las Guardas Reales, y sólo 38 «lanzas», pues las otras tres entran en las cinco que se pagan con el capitán Carlos Enríquez 755.060 14 «lanzas sencillas» a 18.480 mrs., rebajados a 15.680 desde 15 de mayo, y sólo 13 «lanzas», pues otra es de las que se pagan con el capitán Enríquez 203.840

${ }^{21}$ La ordenanza real está en Simancas C.M.C., leg. 43 y 128; es el documento primero del apéndice. También publicada por GARCÍA ORO, J., Galicia en la Baja Edad Media..., 2ª ed., doc. XV.

Cuadernos de Estudios Gallegos, Tomo LII, Fascículo 118, Santiago 2005. (Págs. 239 - 287) 
15 «lanzas» a 17.800 , rebajados a 15.000 desde 15 de mayo, y sólo a 14 «lanzas», pues otra es de las que se pagan con el capitán Enríquez 210.000

10 peones que el gobernador ha de tener en su casa, en la capitanía, a $20 \mathrm{mrs} /$ día cada uno .72 .000

Dos trompetas de la capitanía, a 18.000 mrs. cada uno 36.000

El comendador Fernando de Perea, contino, además de una «lanza doblada» en la capitanía, recibe otros 20.130 para cumplir los 40.000 de su haber de contino

Las tenencias o alcaidías de «las iglesias y fortalezas que sus altezas tienen en el reyno de Galicia» era otro renglón importante del gasto ya que el control de aquellos enclaves por la monarquía garantizaba la paz en el reino y el final de los abusos y latrocinios tan frecuentes en los decenios anteriores a 1480. Los reyes pagaban a cada alcaide, además de su tenencia, el sueldo de una «lanza», y tenían repartidos 175 peones a sueldo entre las diversas fortalezas. Además, habían tomado algunas temporalmente a sus propietarios - grandes señores eclesiásticos o laicos- que, sin embargo, seguían pagando la cuarta parte del sueldo de su guarnición, salvo en ciertos casos en que los reyes hicieron merced al señor de este pago ${ }^{22}$.

Las cantidades para pago de tenencias se redujeron también a partir de 15 de mayo de 1491 en una tercera parte. Parece evidente que, una vez pasado el peligro de desórdenes y pacificado el reino, la monarquía no consideraba necesario mantener el mismo nivel de fuerza militar; los mismos cálculos de reducción se hicieron, por ejemplo, en Granada a partir de 1498: se trata de estimaciones técnicas que permiten comprobar el carácter funcional que tenían aquellos gastos, que no eran suntuarios o debidos a motivos de recompensa política, aunque éstos últimos pudieran tener alguna importancia en ocasiones.

La tenencia más importante era la de Sarria, en manos del alcaide y mayordomo Álvaro de Villasur, con 100.000 mrs/año de sueldo, además de las importantes obras de reparación que se hacían en ella en 1490-1491. La segunda, la de Castro del Rey, con 65.000, de la que era titular Gonzalo Gutiérrez de Celis.

El costo total del pago de tenencias ascendía a 721.761 en el último cuatrimestre o «tercio» de 1490, a 529.732 en el primero de 1491 y a 401.505 en el segundo, una vez aplicada la reducción. Pese a ella, seguía siendo un gasto militar importante, equiparable al de la «capitanía» de gente de caballo de la Hermandad residente en el reino.

\footnotetext{
${ }^{22}$ Fortalezas e iglesias de Orense, Cernades, Burón, Villamayor, Castro de Oro, Villa Juan.
} 
Los «acostamientos» eran gente de caballo («lanzas») vecinos de ciudades y villas del reino, que recibían una cantidad anual a cambio de estar disponibles con sus monturas y armas en caso de llamada regia. Los reyes contaban con 107 «lanças de acostamiento» en el reino, pagadas a $4.000 \mathrm{mrs} /$ año cada una, salvo la de Alvar González de Ribadeneira, que percibía 10.000 «por su persona»-tal vez debido a su calidad social-, lo que supone $438.000 \mathrm{mrs} /$ año en 1491. Los pagos se hacían por nómina firmada por el capitán don Carlos Enríquez y el contador Juan de Arévalo. Serían, seguramente, «lanzas» al modo castellano -ignoramos si «a la guisa», más pesadas, $o$ «a la gineta»-salvo Hernán Pérez de Parragués, que servía con otros nueve escuderos «a la bastarda, a costumbre de Galicia». Había personas que servían con una «lanza» pero también otras que lo hacían con varias, percibiendo las cantidades que proporcionalmente les correspondieran.

Las «libranzas» eran gastos no habituales, diferentes cada año por lo tanto: en 1490-91 son gastos de mensajeros, una suma de $700.000 \mathrm{mrs} /$ año que se entregaba para gastos de la Hermandad general de Castilla, cantidades pagadas al conde de Lemos como consecuencia del acuerdo que los reyes hicieron con él cuando entregó a Ponferrada, y 800.000 mrs. que se libraron a Fernán Núñez Coronel por cédula de la reina (12 de julio de 1490), para repartir entre «ciertas personas de los que salieron heridos e lisiados del real de Baça».

El dinero destinado a la persecución de los malhechores servía para recompensar a quienes los capturaban, y también para pagar el salario de los cinco alcaldes que ejercían en las ciudades cabecera de las «provincias» $-2.000 \mathrm{mrs} / \mathrm{año}$ a cada uno- el del fiscal -1.500- y el del «letrado que ha de ayudar al fiscal», otros 3.000. En total, en 1491 se presupuestaron para estos fines $94.500 \mathrm{mrs}$. pero lo gastado en recompensas fue una cantidad muy inferior y lo mismo ocurrió en los años siguientes, tal vez porque la mayoría de ellas se pagaban con las multas puestas o los bienes requisados a los presos.

El salario de los tesoreros de la Hermandad -Santángel y Pinelo entre agosto de 1490 y la misma fecha de 1493- era siempre de «diez al millar» (uno por ciento) del dinero que gestionaban, lo que suponía algo menos de $60.000 \mathrm{mrs}$./año, y así seguiría siendo hasta 1498. Pero, además, cobran «quince al millar» de los contadores y otros «quince al millar» «que descontays a las personas que en vos son librados». De modo que estos dos $1.5 \%$, que no se reflejan en las cuentas puesto que se detraían directamente de cada libranza, venían a engrosar los haberes de tesoreros y contadores.

La asignación de gastos no varió sustancialmente en los años siguientes. Las cuentas indican nombres de personas y situaciones concretas cuyo conocimiento puede ser útil para historiar diversos aspectos de la Galicia de entonces pero apenas 
cabe comentarlas aquí. Se anota, por ejemplo, la presencia de López de Haro en el real frente a Granada entre mayo y diciembre de 1491, y su viaje a Roma como embajador en 1493, así como diversas partidas pagadas al conde de Lemos y al de Monterrey en 1492, en el caso de este último como compensación por la «cuarta parte» de la contribución de la Hermandad en sus señoríos, de que los reyes le hacían merced.

\section{LAS «PRORROGACIONES» SEXTA Y SÉPTIMA. 1493 A 1498}

Durante las «prorrogaciones» trienales sexta y séptima fue tesorero general de la Hermandad Alonso Gutiérrez de Madrid y Fernando de Villarreal su lugarteniente o colaborador. El receptor principal de la contribución en Galicia era Rodrigo de San Pedro. Los ingresos anuales se mantuvieron ligeramente por encima de los seis millones mientras que los gastos fueron menores, no más de las dos terceras partes casi nunca de modo que el «alcance» anual del que debían responder los tesoreros solía superar los dos millones.

En septiembre de 1494, el gobernador López de Haro y el contador Arévalo recibieron orden real de llevar a cabo un nuevo procedimiento de reparto de la contribución por «encabeçamiento e yguala», que se consideraba más sencillo y ajustado que el anterior, por padrones, además de no obligar a nuevos cálculos cada año puesto que se cobraría «aya mucho o poco número de vecinos»:

Que se faga encabeçamyento e yguala con los pueblos e çibdades e villas e logares e cotos e feligresyas del dicho reyno, çerca de lo que cada uno dellos debe pagar en cada un año de la contribuçion de la Hermandad, cuánto monta por pueblos e por cotos e felygresyas e no por términos e conçejos e personas ni padrones, como se suele e acostunbra faser, porque con ello se quitarían muchas costas e gastos ... e otros ynconvenientes e perjuicios que de ellos se recresçen... ${ }^{23}$.

De todos modos, esto no modificó el total de dinero disponible y el reparto del gasto también continuó siendo semejante pero las cuentas facilitan más detalles y nombres de las personas que ejercen los diversos oficios. Así, las nóminas de salarios durante la «sexta prorrogación» facilitan un cuadro completo:

${ }^{23}$ Carta real de 1494, septiembre 10, Segovia (RGS, f. 137), publicada por FERNÁNDEZ VEGA, L., op. cit., p. 37.

Cuadernos de Estudios Gallegos, Tomo LII, Fascículo 118, Santiago 2005. (Págs. 239 - 287) 


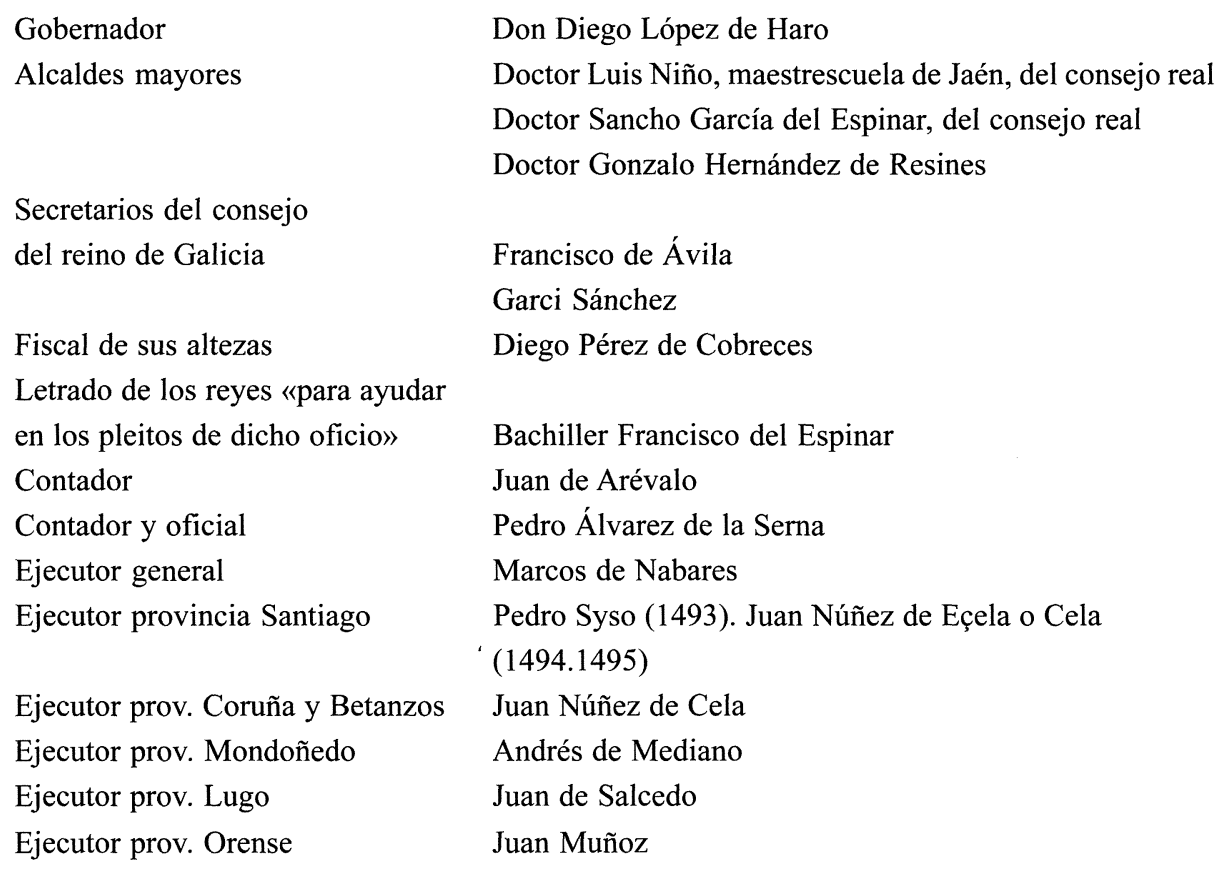

En las cuentas de salarios de los dos años correspondientes a la «séptima prorrogación» se observa el cese del gobernador don Diego López de Haro en marzo de 1497, sustituído por Hernando de Vega, cuyo salario era de 100.000 $\mathrm{mrs}$./año, la mitad que el de su predecesor, y su escolta se reducía a diez peones (72.000 mrs./año). Don Carlos Enríquez de Cisneros conjugaba su oficio militar con el de corregidor de La Coruña y Betanzos, con dos «lanzas» sencillas de acompañamiento. El resto de los oficios han cambiado de titular en algunos casos:

Gobernador
Alcaldes mayores, miembros del
Consejo del reino de Galicia
Secretarios del consejo
Fiscal de sus altezas
Letrado de los reyes «para ayudar
en los pleitos de dicho oficio»
Contador

Gobernador

Don Diego López de Haro. Hernando de Vega (abril 1497)

Doctor Gonzalo Martínez de Villovela

Licenciado Diego Martínez de Astudillo

Licenciado Sancho de Frías. Alonso Maldonado ( $2^{\circ}$ año $)$

Pedro Muñoz de Córdoba

Cristóbal Mejía

Diego Pérez de Cobreces

Bachiller Francisco del Espinar. Luis de Soto ( $2^{\circ}$ año)

Juan de Arévalo 


$\begin{array}{ll}\text { Contador y oficial } & \begin{array}{l}\text { Pedro Álvarez de la Serna } \\ \text { Gil Nieto (contador de la capitanía) }\end{array} \\ \text { Ejecutor general } & \text { Marcos de Nabares } \\ \text { Ejecutor provincia Santiago } & \text { Pedro Syso } \\ \text { Ejecutor prov. Coruña y Betanzos } & \text { Juan Núñez Pardo de Cela } \\ \text { Ejecutor prov. Mondoñedo } & \text { Diego de Mansilla } \\ \text { Ejecutor prov. Lugo } & \text { Gonzalo de Quiroga } \\ \text { Ejecutor prov. Orense } & \text { Sancho de Brizuela }\end{array}$

Los sueldos militares durante la «sexta prorrogación» se repartían entre el mismo gobernador López de Haro, el capitán don Carlos Enríquez, el alférez Juan de Haro, unas 80 «lanzas», de las que diez y diez peones estaban en la «casa» del gobernador y dos en la del capitán Enríquez, el contador de la capitanía, Juan Moro, y dos trompetas. Es de señalar que algunos jueces ejecutores de las «provincias» recibían también sueldo como una «lanza», lo que significa, seguramente, que pagaban con él un acompañamiento armado.

En la «séptima prorrogación», los sueldos militares muestran alguna disminución en el número de «lanzas» de la capitanía que mandaba don Carlos Enríquez de Cisneros y en las asignadas a la escolta del gobernador y a la suya propia.

Así, don Diego López de Haro había tenido un sueldo de 200.000 mrs/año por capitán y «diez lanzas de su casa», mientras que Hernando de Vega sólo dispuso de cinco, aunque no se expresa si también disminuyó su propio sueldo. Enríquez de Cisneros mantuvo un sueldo de 106.000 , que comprendía también el de dos «lanzas» de acompañamiento, aparte del salario que tenía como corregidor de La Coruña desde enero de 1497. La capitanía continuaba teniendo un contador propio, Gil Nieto, dos trompetas y 28 «lanzas»más entre «dobladas» y «sencillas». Estas cifras apenas se alteran en 1498, de modo que había habido una reducción a menos de la mitad con respecto a los efectivos mantenidos hasta 1496.

La mayor novedad de las cuentas de la sexta y séptima «prorrogaciones» es que facilitan relaciones nominales de los alcaides de las veinticuatro fortalezas -en 1493 - cuya tenencia pagaban los reyes, e indican la titularidad de las fortalezas, que podían ser de la corona o tomadas a diversos señores. También se detalla el nombre de las treinta y seis personas que tenían asentado acostamiento con una o más «lanzas», depende de los casos, puesto que en total son 116 «lanzas», algunas de ellas pesadas $\mathrm{u}$ «hombres de armas» $\mathrm{y}$ la mayor parte, por lo que parece, ligeras $o$ «a la jineta». Tiene interés conocer los nombres de aquellos titulares de tenencias y acostamientos porque componen una nómina de personas de confianza política de la administración regia en Galicia. 
Las cuentas de la «séptima prorrogación» muestran que las tenencias han descendido a 23 a mediados de 1496 y sólo son 21 desde finales de aquel año, y que los «acostamientos» se pagaban a 32 ó 33 personas, que estaban obligadas a servir con 100 a 110 «lanzas». Así, pues, en tenencias y acostamientos no hubo reducción apreciable, al contrario de lo que sucedía con los efectivos de la «capitanía» de la Hermandad destacada en Galicia, sino que se mantuvieron los compromisos de los años anteriores con personas radicadas en el reino.

Entre las libranzas del trienio correspondiente a la «sexta prorrogación» destacan la continuidad de las indemnizaciones pagadas al conde de Lemos para compensar los daños sufridos en Ponferrada, la cesión de alguna tenencia de fortaleza y las participaciones que tenía en los pagos hechos por sus señoríos a la contribución de la Hermandad; hay también indemnizaciones, por este motivo, a los condes de Ribadeo, Monterrey y otros señores. Destacan, igualmente, la mención al avituallamiento de la «armada de 'Vizcaya» en septiembre de $1493^{24}$, el flete en Muros de una nao que participó en el segundo viaje de Cristóbal Colón y los pagos de primeros preparativos de la nueva «armada deVizcaya» que llevó a la infanta Juana a Flandes ${ }^{25}$; las obras en fortalezas y en las casas del gobernador en La Coruña, y diversos correos, entre ellos el enviado a la corte para dar la noticia de la muerte de Juan II de Portugal.

Las libranzas de la «séptima prorrogación» muestran las habituales compensaciones a los condes de Lemos, Monterrey y Ribadeo por la contribución de Hermandad cobrada en sus señoríos, además de dar noticia de alguna obra en fortalezas y de las honras fúnebres por el príncipe don Juan hechas en Santiago de Compostela.

En el apartado de persecución de malhechores, se paga también el pequeño salario de los dos alcaldes de la Hermandad que había en cada una de las cinco provincias gallegas. Los «premios» por capturas siguen siendo muy pocos debido a que eran un procedimiento de pago supletorio, utilizado sólo cuando el malhechor no tenía bienes con que compensar a sus captores, de modo que no puede relacionarse la escasez con otra paralela de los delitos al no ser procedimiento válido para conocer cuáles eran la frecuencia y características de éstos. Las descripciones de cada caso en las cuentas son, además, demasiado someras y apenas permiten comentario.

\footnotetext{
${ }^{24}$ Sobre esta armada vid. LADERO QUESADA, Miguel Ángel, «La Armada de Vizcaya (14921493). Nuevos datos documentales», En la España Medieval, 24 (2001), 365-394.

${ }^{25}$ LADERO QUESADA, Miguel Ángel, La armada de Flandes. Un episodio en la política naval de los Reyes Católicos (1496-1497), Madrid, Real Academia de la Historia, 2003.
} 


\section{LOS «REPARTIMIENTOS DE PEONES POR VÍA DE HERMANDAD» DE 1495 Y 1496}

Además de los ingresos y gastos relativos a la "contribución ordinaria», en 1495 y 1496 se repartió otra extraordinaria para pago de «peones» con destino a la guerra que los reyes sostenían en Nápoles y el Rosellón contra Carlos VIII de Francia. Estas contribuciones extrordinarias ya habían sido frecuentes durante la conquista de Granada pero ahora se aplicaban a conflictos externos al ámbito de Castilla, aunque en Galicia existía el antecedente de las tropas enviadas a Bretaña en 1490, al mando del gobernador López de Haro y del capitán Carlos de Cisneros, formando parte de una expedición más amplia integrada por varias capitanías de la Hermandad $^{26}$. La Hermandad de Galicia participó en el reparto de 1495 con 5.400 .000 mrs., de los que los reyes rebajaron la tercera parte, de modo que el cobro fue de en torno a tres millones seiscientos mil maravedíes, menos algunas «quitas» $\mathrm{y}$ «suspensiones».

La cuenta añade un dato de interés para la demografía fiscal del momento: la contribución se repartió entre 50.017 vecinos que tenía el reino de Galicia a estos efectos, a razón de 72.5 maravedíes cada uno (casi dos reales y medio). Si se aplica el mismo cómputo al pago de la «contribución ordinaria», a razón de cuatro reales por vecino, se comrpueba que cuadra la suma total de 200.068 reales o 6.202.108 mrs. al año.

Con el dinero del «repartimiento de peones» extraordinario se pagó, ante todo, a los «mill peones que el dicho año se repartyeron en Galizia para yr a Seçilia con Alvaro de Torres», pero sabemos que el resultado de esta recluta, que también se hizo en Asturias, dejó mucho que desear, porque bastantes de aquellos peones desertaron antes de embarcar en Cádiz y Alicante y, al cabo, llegaron a Sicilia no más de 400 gallegos y asturianos, tan «mal armados que no salío de España muchos días había tan vil gente», en opinión de Jerónimo Zurita ${ }^{27}$. El pago no fue directo, sin embargo, sino que, como casi todos los demás de la guerra, se hizo

\footnotetext{
${ }^{26}$ Sobre su cobro durante la guerra de Granada, LADERO QUESADA, Miguel Ángel, Castilla y la conquista del reino de Granada, Granada, 1993 ( $3^{\text {a }}$ ed.). Bretaña en GARCÍA ORO, op. cit., p. 226 y SUÁREZ FERNÁNDEZ, L., Politica internacional de Isabel la Católica, Valladolid, 1969, III, pp. 51-67. Su empleo en las guerras del Rosellón y Nápoles en LADERO GALÁN, Aurora y LADERO QUESADA, Miguel Ángel, «Ejércitos y armadas de los Reyes Católicos: algunos presupuestos y cuentas de gastos entre 1493 y 1500», Revista de Historia Militar, 92 (2002), 43-110.

${ }^{27}$ ZURITA, Jerónimo de, Historia del Rey don Hernando el Católico: de las empresas y ligas de Italia, Ed. A. Canellas López, Zaragoza, 1989 y ss., Libro Segundo, cap. 11, julio-agosto 1495.
} 
enviando buena parte de la recaudación al tesorero «de lo extraordinario» de los reyes, Alonso de Morales, que luego lo redistribuía en los pagos que era menester hacer para el desarrollo de la guerra.

Otra parte notable de la contribución se destinó a pagar algunos «bastimentos de la armada que fue con el archiduquesa», esto es, provisiones compradas y preparadas en la misma Galicia para aquella flota, que llevó a la infanta Juana a Flandes en agosto de 1496 para su matrimonio con el archiduque Felipe de Habsburgo ${ }^{28}$.

En 1496 hubo un segundo «repartimiento de peones» pero no están las cuentas correspondientes entre las que hemos manejado. Sin embargo, sabemos que en noviembre de 1496 se hizo una pesquisa para averiguar por qué de los 3.000 peones gallegos que debían enviarse a la frontera del Rosellón no se había alistado a más de mil pese a los compromisos previos contraídos y pagados, sin duda con dinero del citado repartimiento, cuyas características serían muy similares a las del de $1495^{29}$.

Los documentos que presentamos a continuación proporcionan informaciones nuevas y muy amplias sobre la Hermandad y su funcionamiento en Galicia así como numerosos datos de interés para la historia de las estructuras políticas del reino en los años de cambio rápido que presenciaron la implantación de una autoridad monárquica mucho más efectiva, por obra de los Reyes Católicos.

El documento $\mathrm{n}^{\circ} 1$ es una ordenanza o nómina de pago firmada por los reyes en abril de 1491, que puede servir como referencia y punto de partida general. Los documentos $\mathrm{n}^{\circ} 2,4$ y 7 muestran la sucesión de pagos hechos con cargo a la «contribución de la Hermandad» entre agosto de 1490 y agosto de 1498. El documento $\mathrm{n}^{\mathrm{o}} 3$ es un resumen general de los cargos y datas del trienio de la «sexta prorrogación», pero afirma que corresponde al periodo agosto 1492-agosto 1495, cuando tal prorrogación corresponde a las mismas fechas del trienio 1493-1496; el $\mathrm{n}^{\mathrm{o}} 6$ se refiere al trienio agosto 1495 -agosto 1498 afirmando que es la «séptima

${ }^{28}$ V. el detalle de las operaciones y el papel de Galicia en ellas en LADERO QUESADA, Miguel Ángel, La armada de Flandes (1496-1497), op, cit.

${ }^{29}$ GARCIA ORO, op. cit., p. 227, carta real al gobernador López de Haro, de 17 de noviembre de 1496 (Simancas, R.G.S.). El mismo autor añade otro documento de R.G.S., septiembre 1497, f. 235, en el que se narra la resistencia de los vecinos de Puentedeulla al pago de la contribución de dos reales y medio que tomaba el cogedor de la Hermandad y regidor de Santiago, Pedro Siso, y los castigos arbitrarios que sufrieron. Los sucesos relatados pueden corresponder al año 1496. 
prorrogación», que en realidad corresponde a agosto 1496 hasta la supresión de la Hermandad en agosto de 1498. Ignoro a que obedece esta atribución errónea en virtud de la cual sobra un año en uno de estos dos documentos, pero he preferido presentarlos tal cual están. Por último, el documento $\mathrm{n}^{\circ} 5$ detalla el «repartimiento extraordinario» de 1495 para la recluta de peones. No he encontrado la cuenta relativa al segundo «repartimiento», en 1496.

No se trata de editar una transcripción literal de las cuentas, porque no tendría razón de ser dadas sus características, sino un extracto completo de su contenido, ordenado y en lenguaje actual. Para facilitar la búsqueda eficaz de referencias, se ha dado a cada asiento de las cuentas un número convencional, del uno al 417 , al que se refieren los índices de nombres de personas y lugares. 


\title{
APÉNDICE DOCUMENTAL ${ }^{30}$
}

\author{
1491, abril 7, Sevilla \\ Ordenanza real sobre lo que se ha de pagar con cargo a la Hermandad de Galicia.
}

(Simancas. C.M.C. primera época, Leg. 43).

Ordenanzas dadas por los reyes, y refrendadas por el secretario Juan de Coloma, sobre lo que se paga con la contribución de Hermandad de Galicia. Dirigidas a don Diego López de Haro, capitán, gobernador y justicia mayor de los reyes en el reino de Galicia, al contador Juan de Arévalo, contino de la casa real, a Pedro Alvarez de la Serna, contador de la hermandad del reino de Galicia por el obispo de Almería, a Alfonso de Quintanilla, y a Gonzalo Moro, contador del sueldo de la gente de la capitanía del gobernador López de Haro por Alonso de Quintanilla.

Los reyes ordenan que desde el próximo 15 de mayo y por cuanto «nuestra merçed e voluntad fuere» se pague con fondos de la contribución ordinaria de la Hermandad de ese reino de Galicia, los salarios e sueldo de gente e tenençias de fortalezas e otras cosas adelante contenidas, en esta guisa»:

\section{Salarios}

2. Don Diego López de Haro, salario del oficio de gobernador, cada año 200.000

3. Doctor Sancho García del Espinar, del consejo real y alcalde mayor del reino de Galicia. 200.000 al año. 150.000 desde el próximo 15 de mayo 150.000

4. Doctor del Espinar, por juez ejecutor de la provincia de Segovia, 70.000 al año, y desde el próximo 15 de mayo

5. Licenciado Antonio Cornejo, del consejo real y alcalde mayor del reino de Galicia

6. Contador Juan de Arévalo, al año 180.000

7. Pedro Alvarez de la Serna 50.000

8. Alonso Alvarez y Francisco de Avila, escribanos del consejo real, a 10.000 .

9. Marcos de Navares, ejecutor general de la Hermandad .......................................... 80.000

10. Jueces ejecutores de la Hermandad de las provincias de Santiago, La Coruña, Mondoñedo, Lugo y Orense, 10.000 a cada uno hasta 15 de mayo, y 5.000 en lo sucesivo

\section{Sueldos}

11. Gobernador López de Haro, sueldo por capitán 200.000

12. Capitán Carlos de Cisneros, para él y para 5 lanzas 106.000

13. Gonzalo Moro, contador de la capitanía, de ayuda de costa, además de una 'lanza doblada'

\footnotetext{
${ }^{30}$ Siglas utilizadas: c., cornado (1/6 de maravedí); 1., «lanza»; 1.d., «lanza doblada»; m. o mr., maravedí; p., peón; v. o vec., vecino.
} 
14. Al alférez de la capitanía, además de una 'lanza doblada'

15. 41 'lanzas dobladas' que ahora sirven en las dichas capitanías, a $23.570 \mathrm{~m}$ cada una al año hasta 15 de mayo, en que pasarán a cobrar 19.870, 'segund se paga la otra gente de nuestras Guardas'. Y sólo a 38 lanzas, pues las otras 3 ha de haberlas Carlos de Cisneros a cuenta de las 5 que se le asignan

16. 14 'lanzas sencillas' a $18.480 \mathrm{~m}$., rebajados a 15.680 desde 15 de mayo, y a 13 'lanzas' (la otra se asigna a Carlos de Cisneros)

17. 15 lanzas 'del [ .....] menor' a 17.800 , rebajados a 15.000 y a 14 lanzas, puesto que la otra se asigna a Carlos de Cisneros

18. 10 peones que el gobernador ha de tener 'de vuestra casa' en dicha capitanía a $20 \mathrm{mrs}$. día cada uno

19. Dos trompetas de la capitanía, a 18.000 cada una 36.000

20. El comendador Fernando de Perea, contino, además de una 'lanza doblada' en la capitanía, otros 20.130 mrs. para cumplir los 40.000 que ha de recibir por contino

\section{Tenencias de fortalezas}

21. Alvaro de Villasur, alcaide y mayordomo real de la villa de Sarria, al año

22. Gonzalo Gutiérrez de Çelis, por la tenencia de Castro de Rey, al año 65.000

23. En las fortalezas reales en el reino de Galicia se ha pagado 'hasta aquí' una 'lança A cada uno de los alcaides', y además se paga a ciertos peones que son entre todas las fortalezas 175 peones.

Los reyes han mandado «tornar a sus dueños» algunas de tales fortalezas, y los dueños pagan la cuarta parte del sueldo de lanzas y peones, salvo las fortalezas e iglesias de Orense, Çernades, Burón, Villamayor, Castro de Oro, Villa Juan. Además, quitan la tercera parte del sueldo desde 15 de mayo.

En total se ha de pagar.

\section{Acostamientos}

24. 107 'lanças de acostamiento que en el dicho reyno de Galizia mandamos asentar' a 4.000 cada una al año, y 10.000 que ha de haber 'por su persona Alvar Gonzalez de Rivadeneira'

\section{Persecución de malhechores}

25. «Para la persecución de los malhechores del dicho reyno», con lo que se paga además a los 5 alcaldes de las cabeceras de las provincias, a 2.000 cada uno al año, «al letrado que ha de ayudar al fiscal» $3.000, \mathrm{y}$ al fiscal, 1.500. En total 94.500

Total $3.742 .196 \mathrm{mrs}$ 
Cuenta de la «quinta prorrogación» (agosto de 1490 a agosto de 1493). Años octavo a décimo de la Hermandad de Galicia (primero, segumdo y tercero de la tesorería de Luis de Santángel y Francisco Pinelo).

(Simancas, C.M.C., leg. 134).

Cargos y datas generales

Año primero

Cargo .

Data 9.949 .152

Alcance

Año segundo

Cargo

6.118 .718

Data

Alcance

Año tercero

Cargo

Data

Alcance

Cargo detallado en reales

Provincia

Santiago

La Coruña y Betanzos

Mondoñedo

Lugo

Orense

Total

en maravedíes deudas con tesoreros de años pasados

900
581,5
298
377
1.018
3.075

\section{Año octavo}

63.368

29.849

14.926

50.608

37.116

195.867

6.167 .202
Año noveno

$$
63.976
$$

30.312

15.216

50.690

37.184

$197.378^{31}$

6.118 .718
Año décimo

63.904

29.660

14.943

51.364

37.300

$197.162^{32}$

6.112 .333

\section{Suspensiones del año octavo (primero de la tesorería de Santángel y Pinelo)}

(en reales. Un real equivale a $31 \mathrm{mrs}$.)

1. La ciudad de Santiago, la tercera parte de 1.500 reales, esto es, 500 , que

'sus altezas mandan que no se cobren por faser merçed a la dicha çibdad' ................... 500

2. De los 43 excusados de la obra de la iglesia de Santiago .................................................. 172

3. Dos excusados del monasterio de San Martino, en la provincia de Mondoñedo ................... 8

4. 34 excusados de la iglesia de Santa María de Zebrero, en la provincia de Lugo ............... 132

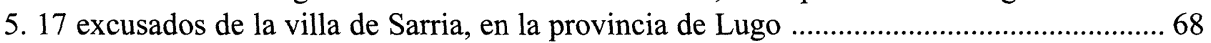

6. «De la tierra del Bullo, que es en la provincia de Orense, se suspenden 800 reales porque diz que tienen previllegio de sus altezas por que no deven pagar hermandad» .....800

Total 1.680 reales, que son 52.080

${ }^{31}$ Se les cargan 3.200 reales de deudas que cobraron, pero se tacha la partida

${ }^{32}$ Se les cargan 7.544 reales de deudas, pero se tacha la partida 
7. Se descarga a los tesoreros 7.173 reales, que parece se les dejó a deber en dicho año, de este modo:

1. Provincia de Santiago con el obispado de Tuy

2. Provincia de La Coruña y Betanzos.

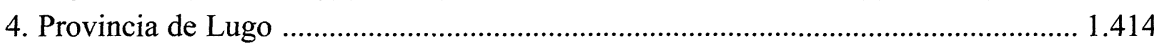

5. Provincia de Orense ....................................................................................... 2.104,5

Son, en total, $222.363 \mathrm{mrs}$. (tachado), que los tesoreros cargarán sobre sí al año siguiente, cuando los cobren.

\section{Suspensiones del año noveno}

Se les reconocen $52.080 \mathrm{mrs}$., como el año anterior, por lo que los reyes mandan que no se cobre Pero está tachado el importe total de otras cantidades que no cobraron:

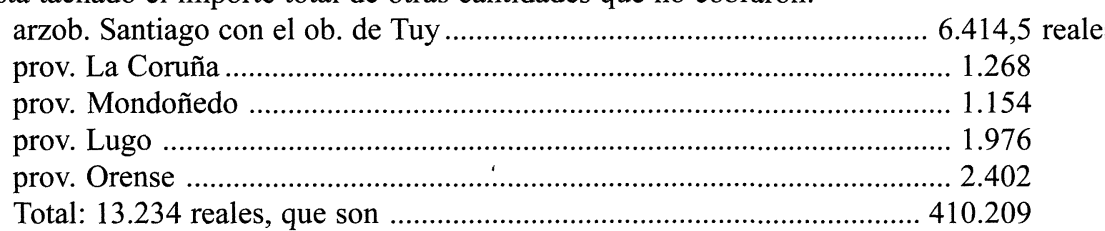

\section{Suspensiones del año décimo}

A la ciudad de Santiago, la tercera parte de los 1.600 reales que se le cargaron este año

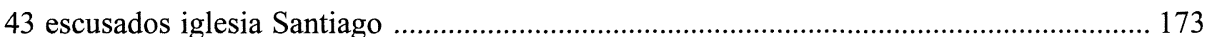

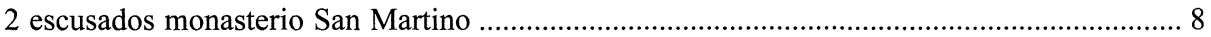

29 vecinos cargados a la villa de Sarria, que los reyes mandan no cobrar ............................. 116

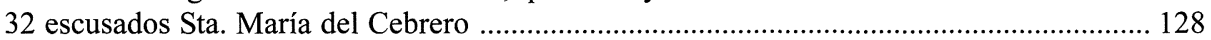

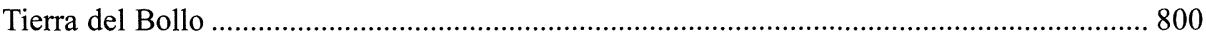

son 1.758 reales, o $54.498 \mathrm{mrs}$.

Otros 5.230 reales que les quedaron debiendo (son $162.254 \mathrm{mrs}$.), pero está tachado:

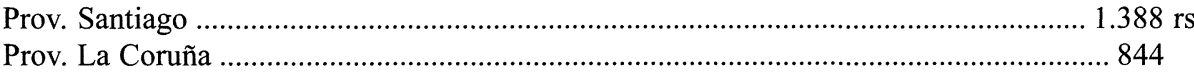

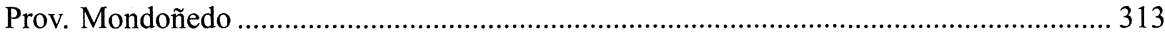

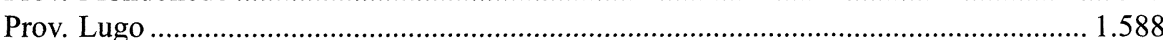

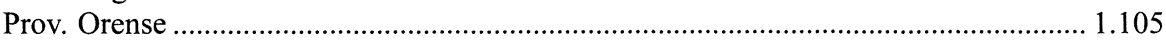

Data detallada

29. Pagos hechos a don Diego López de Haro, 'nuestro gobernador en el reyno de Galizia', a la gente de su capitanía, a los 'del nuestro consejo e a los juezes esecutores e otros ofiçiales de la dicha hermandad que en el dicho reyno residen, e a los alcaydes de las iglesias e fortalezas e a los caualleros e escuderos que de Nos tienen acostamiento e a otras personas que Nos mandamos librar en la contribución del dicho reyno», más el salario de los tesoreros, de diez al millar (además de otros 15 al millar «que cobrays de los contadores» y de los otros 15 al millar «que descontays a las personas que en vos son librados»), y con las 700.000 que de la contribución de la Hermandad de Galicia se toman cada año para cumplir las libranzas que se hacen en la contribución destos reynos (se refiere a Castilla)

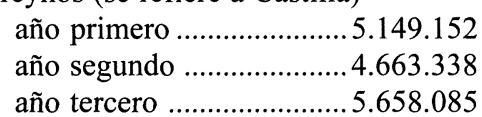


30. Más otros 800.000 de dinero de la Hermandad de Galicia que dieron por orden real a Fernán Núñez Coronel, «que los ovo de aver para pagarlas a algunas personas que reçibieron daños a nuestro serviçio en el çerco de la çibdad de Baça», y 12.000 de su salario de tesoreros, que no los descontaron a Fernán Núñez. Total, a añadir al año primero

\section{Data del año octavo}

(los libramientos los firma el gobernador don Diego López de Haro y el contador Juan de Arévalo. Tienen para ello poder de los reyes, por cédula de 27 febrero 1491, aunque seguramente recibieron otros poderes anteriores, tal vez cada año. O bien los libra el contador por cédula real)

\section{Salarios}

31. Al gobernador don Diego López de Haro «e a los otros del consejo e ofiçiales que residen en el reyno de Galizia, por nómina de los dichos governador y contador Juan de Arévalo», desde $1^{\circ}$ septiembre 1490 hasta fin de octubre .......... $151.583 \mathrm{~m} .2$ cornados

32. Gobernador, consejo e ofiçiales. etc. noviembre y diciembre 1490 145.083

33. Gobernador, oidores, contador.y otras personas, salarios y quitaciones del primer tercio de 1491

\section{Sueldos}

34. A don Carlos Enrríquez, capitán de sus altezas, tiene 106.000 mrs. al año.

Se le paga desde primero de septiembre

«los quales se le libraron así juntos (fecha 10 septbre. 1490) porque yva a Bretaña por mandado de sus altezas por capitán de la gente que sus altezas mandaron yr desde Galizia al ducado de Bretaña»

35. Al gobernador y a los caballeros y escuderos de su capitanía, septiembre y octubre 1490

36. Gobernador y su capitanía (incluye siempre trompeta y herrador) de sueldo y acostamiento y por pérdidas de caballos y armas, noviembre y diciembre 1490 .... 203.288

37. Gobernador y gente de su capitanía (el gobernador tiene una parte de la capitanía 'en su casa': 4 lanzas dobladas, 6 sencillas, 10 peones). Sueldo del tercio primero de 1491

38. Sueldo de la lanza doblada de un escudero de la capitanía en marzo y abril de 1491

39. Juan de Chillón, herrador de la capitanía. Salario y quitación de 1 enero a 15 mayo 1491 en que fue despedido

40. Doctor del Espinar, licenciado Cornejo, capitán don Carlos y otras personas que tienen salarios en el reino de Galicia, con ciertos escuderos de la capitanía del gobernador, según nómina, de mayo y junio de 1491

41. Gobernador, oidores y otras personas que tienen salarios en Galicia y a la gente de la capitanía del gobernador, por nómina. Para terminar de ser pagados hasta fin de agosto de 1491

42. Un escudero de la capitanía, sueldo de su lanza doblada de 1 mayo a 9 julio 1491

43. Otro escudero de la capitanía, sueldo de su lanza doblada de 1 julio a 31 dic. 1491 


\section{Tenencias}

44. A los alcaydes «de las iglesias e fortalezas que sus altezas tienen en el reyno de Galizia», por nómina dada por el gobernador y contador. Tenencias del «tercio postrimero» de 1490 (septiembre a diciembre), «sin la quarta parte que pagan los señores de algunas de las fortalezas»

45. 5 espingardones y 6 paveses comprados para la fortaleza de Villalba. Se pagan al comendador Hernando de Perea

46. Arias de Armesto, alcaide que fue de la fortaleza de Sotomayor, para completar el pago de su tenencia, que ejerció desde 20 de septiembre de 1486 hasta 5 de abril de 1488

47. Alvaro de Villasur, alcaide de Sarria. Gastó 79.129 en obras en la fortaleza de Sarria («chapar la cava», «reparar la fortaleza» y hacer dos chimeneas en ella). Para completar el pago de sus gastos

48. Alcaides de las fortalezas que los reyes tienen en Galicia, descontando la cuarta parte, etc. Pago del tercio primero de 1491

49. Alcaides que tienen fortalezas en el reino de Galicia, etc. Tercio segundo de 1491

50. Alvaro de Torres, alcaide de la fortaleza de Castro Doro, se le da de su tenencia, por orden real, una cantidad que 'segund las ordenanzas' se le había detraído en el tercio segundo de 1491 . Son $5.596 \mathrm{~m} .2 \mathrm{c}$.

\section{Acostamientos}

51. Caballeros y escuderos que tienen acostamiento de los reyes en el reino de Galicia, por nómina «de los dichos don Carlos e contador Juan de Arévalo». Acostamiento de todo el año 1490.- No se pagó el acostamiento de 10 lanzas que tiene Fernán Pérez Parragués 'por algunas cosas que cunplen a serviçio de sus altezas' 386.333 m. 2 c.

52. Hernán Pérez Parragués, de acostamiento para él y 9 escuderos 'con que ha de servir a la bastarda, a la costunbre de Galizia'. Año 1490 40.000

\section{Libranzas}

53. A dos mensajeros que trajeron cartas de Bretaña a la corte.

Libramiento de 11 oct. 1490

54. Dr. Sancho García de Espinar, por su salario de juez ejecutor de la provincia de Segovia a 70.000 por año, de 15 agosto 1490 a 15 mayo 1491 , y desde 15 mayo 91 a 15 agosto a 46.666

55. A un mensajero enviado a la corte, a Sevilla

56. Juan de Salcedo, juez ejecutor de la hermandad de la provincia de Lugo, para completar el pago de los $200.000 \mathrm{mrs}$. en que se remató la fortaleza de Torres y los vasallos de la Ribera de Aguera, que él sacó en almoneda y lo traspasó a los reyes

57. Don Rodrigo Enríquez Osorio, conde de Lemos (libram. 24 junio 1491), para acabar de pagarle los $467.916 \mathrm{mrs}$. 'que el conde hubo de haber de la hermandad de las provincias de Lugo y Orense por virtud del finequito que sus altezas le mandaron dar quando entregó a Ponferrada'. Son

58. Se traspasa para gastos de la hermandad de Castilla 700.000

59. Cinco resmas de papel para escribir las cuentas de la hermandad del reino de Galicia, costaron 900 mrs., y pago a algunos mensajeros que llevaron las cartas 
de convocatoria a los procuradores de las ciudades, villas y lugares del reino de Galicia para que viniesen a la junta que se hizo en Lugo el año 1491. Total...

60. Al repostero de camas Alonso de Salazar, ayuda de costa «de un camino que sus altezas le mandaron yr al reyno de Galizia». Libr. 15 marzo 1493 ...

61. Fernán Núñez Coronel (cédula de la reina de 12 julio 1490. sic) que se le libran para repartir «a çiertas personas de los que salieron heridos e lisiados del real de Baça»

6. Malhechores

62. A Ruy Díez de Tablares, porque prendió un malhechor que fue ajusticiado en Lugo «e no se hallaron bienes suyos»

\section{Salario de tesoreros}

63. Salario de los tesoreros, a razón de 10 al millar de lo que libren

64. Se les descarga una cantidad por no haber cobrado derechos de 15 al millar en ciertos pagos

total de la data

alcance contra los tesoreros

\section{Data del año noveno}

\section{Salarios}

65. Al gobernador, los del consejo, etc. por nómina, salario tercio postrimero 1491 ....288.233

66. Gobernador, oidores, etc. enero y febrero de 1492

67. Gobernador, oidores del consejo, etc. por nómina (las suele dar el capitán don Carlos y el contador Juan de Arévalo), marzo y abril de 1492

68. Oidores y otras personas, por nómina, mayo y junio de 1493 (sic)

69. Gobernador, oidores y otras personas, 1 mayo a 15 agosto 1493 (sic)

\section{Sueldos}

70. Gobernador y su capitanía (contador Gonzalo Moro), sueldo tercio postrimero 1491

71. Un escudero de la capitanía, octubre a diciembre 1491

72. Gobernador y capitanía enero y febrero de 1492

73. Un escudero de la capitanía, sueldo 1 dic. 1491-fin febrero 1492

74. Un escudero de la capitanía enero y febrero 1492

75. Un escudero de la capitanía, enero y febrero 1492

76. Un escudero de la capitanía, lanza doblada, de 1 septiembre a 31 diciembre 1491 ..... 6.633

77. Juan Martínez Pardo de Cela, sueldo de su lanza doblada de 1 marzo a 31 dic. 1491 .. 17.245

78. Gobernador y capitanía. marzo y abril 1492

79. Pagos sueltos de sueldos a escuderos de la capitanía

[833; 10.000 (de 1485-86); 3.995]

80. Caballeros y escuderos de la capitanía, mayo y junio de 149 (sic)

81 . Gobernador y capitanía, 1 mayo a 15 agosto 1493 (sic) 264.069

\section{Tenencias}

82. Alcaides de fortalezas de los reyes en Galicia, por nómina, pago hasta fin diciembre 1491 
83. Alcaides de fortalezas, tercio primero de 1492

395.870

84. Alvaro de Torres, alcaide de Castro Doro, tenencia tercio final de 1491 .......24.333 m. 2 c.

85. Pedro Siso, alcaide de la fortaleza de Peñaflor, cuarta parte tenencia 1492 ................ 10.967

86. Alcaides de fortalezas, tercio segundo de 1493 (sic).

387.508

4. Acostamientos

87. Acostamiento de caballeros y escuderos, nómina de 1491 todo el año

5. Libranzas

88. Gastos en mensajeros, papel, pago a personas «que descubrieron çiertos veçinos que estavan encubiertos

89. Extraordinario. Don Alonso Enríquez, obispo de Lugo (cédula real 17 septiembre 1492), que había pagado a los alcaides de la fortaleza de Lugo de la cuarta parte de 1487 a 1490 , y los reyes se los mandan devolver, reteniendo 10.000 para obras en la fortaleza de Lugo (que también se les cargan)

6. Malhechores

90. Pedro de Ledesma, corregidor que fue de Vayona (sic), de costas que hizo en prender a Pedro de Mondin, malhechor que fue ajusticiado por ladrón

91. Rodrigalvarez de la Puebla del Burullón, por prender a un malhechor que fue traído a Lugo y asaeteado

92. Dos criados del alcaide de Torres, por prender al malhechor Pedro Herrán, que fue ahorcado

93. Pagos a captores de malhechores en 1493 [3.000;2.000;2.000; 2.635] 9.635

[concluye incompleto]

Data del año décimo

\section{Salarios}

94. Licenciado Antonio Cornejo, salario de octubre de 1492, a 120.000 año

95. Gobernador y las otras personas, etc. septiembre y octubre 1492

96. Doctor don Luis Niño, maestrescuela de Jaén, alcalde mayor de Galicia

Salario desde 3 agosto 1492 en adelante (son 100.000 al año; le pagan ahora 9.333) y 20.000 más de merced real.

97. Gobernador y las otras personas ... noviembre y diciembre de 1492

98. Consejo y otras personas que están en el reino de Galicia, enero-febrero 1493 ...... 131.174

99. Consejo y otras personas que están en Galicia, marzo-abril 1493

\section{Sueldos}

100. Gobernador y capitanía, septiembre y octubre 1492

101. A escuderos de la capitanía, que se les había retenido en 1491 por no haber tenido «dobladuras» algún tiempo o «porque avían estado en sus casas más tiempo de las licencias que les fueron dadas»

102. A Diego de Reinoso, escudero de la capitanía, que estuvo con el gobernador en el real de Granada entre mayo y fin diciembre 1491

103. Gobernador y capitanía noviembre y diciembre 1492

104. Medio mes de pago al alférez de la capitanía

105. Capitán don Carlos y caballeros y escuderos de la capitanía, enero-febrero $1493 \quad \ldots 102.055$

106. Capitán don Carlos, caballeros y escuderos de la capitanía, marzo-abril 1493 ...... 102.753 


\section{Tenencias}

107. Alcaides del reino de Galicia. Tercio final del año 1492

108. Alcaides de las fortalezas del reino de Galicia, tercio primero de 1493

109. Diego de Valderrábano, alcaide de la fortaleza de Monte Sagro, de la cuarta parte de la tenencia, desde 2 julio 1492 hasta fin de ese año, ya que por orden real no lo pagó el arzobispo de Santiago

\section{Acostamientos}

110. Caballeros y escuderos de acostamiento. año 1491 (nómina 12 abril 1493)

111. Al mismo Juan Núñez y a Juan Pardo, su hermano, por acostamiento de dos lanzas que se acrecentaron a Juan Núñez y de una que se asentó con Juan Pardo, a 4.000 al año cada una, desde 1 enero 1490 hasta 31 diciembre 1491

\section{Libranzas}

112. «Al dicho governador e a çiertos escuderos de su capitanía que fueron con él a Roma», nómina de 6 de abril de 1493, y al gobernador, las otras personas, etc. y a las 4 lanzas dobladas, 6 , sencillas y 10 peones de su capitanía que están con él.....

113. Conde de Lemos, por su finequito, ya que se le debían (no lo había cobrado de la contribución de Hermandad de sus tierras, ni en Sarria), y fueron librados al conde de Lemos su abuelo «que ovo de aver del çerco de Toral e porque se le avían descontado al dicho conde». libr. 17 sept. 1492

114. Conde de Lemos, libr. 17 sept. 1492, de las cuartas partes de las tenencias de las fortalezas de Monforte de Lemos, Caldelas y Moechin, pagadas por el conde «después que fueron conplidos los dos años que el ovo de pagar las tenençias de las dichas fortalezas». Se le pagan por Monforte y Caldelas, desde septiembre hasta final de 1488, a razón de una lanza 'doblada' cada una (24.520 al año) y diez peones ( $20 \mathrm{mrs}$./día cada uno, que son $72.000 \mathrm{al} \mathrm{año),} \mathrm{y} \mathrm{por} \mathrm{la} \mathrm{fortaleza} \mathrm{de}$ Moechen, desde fin de septiembre hasta fin de 1488, a razón de una lanza sencilla (17.000 al año) y cinco peones. Total del pago .....

115. Fernán Pérez Parragues. Ayuda de costa dada por los reyes

116. Conde de Monterrey, libr. del contador Juan de Arévalo 17 sept. 1492, por cédula real. De la cuarta parte de la hermandad de sus tierras desde 16 agosto 1486 hasta 15 agosto 1491 , a 100.000 al año

(da 200.000 de ellas al obispo de Ávila, hoy arzobispo de Granada, por 'çierta conposyçion' que hizo el conde con él).

117. Juan Núñez de Cela, regidor de Betanzos. Ayuda de costa dada por los reyes ........ 30.000

118. Pedro de Losa, ayuda de costa (todos estos libramientos de Arévalo son de 17 sept. 92)

119. Alonso de Villalón, vec. Villalón, libr. 20 diciembre 92. Por cierto pescado que

le fue tomado para el cerco de Ponferrada por el conde de Lemos. Se le libran sobre el millón «que sus altezas ovieron de mandar librar al conde de Lemos»

120. Martín de Reino, libramiento de 8 enero 1493, por «los serviçios que a sus altezas hizo en la guerra de los moros en el real de Granada» y gastos que esto le causó .... 30.000

121. Dados para gastos de la Hermandad de Castilla 700.000

122. Lorenzo de Madrid, por viaje a Galicia y regreso, para traer cuentas y documentos de la hermandad a los contadores mayores. libr. 26 agosto 1495 4.000 
6. Malhechores

123. Captores de malhechores $[2.000 / 1.000 / 620]$

7. Salario de los tesoreros

124. Salario de diez al millar de los tesoreros

Total de la data de este 'año terçero' de Santángel y Pinelo

Alcance contra los tesoreros

(El cargo es de 6.112.333)

[125] Toma de cuentas a Santángel y Pinelo. Parte correspondiente a Galicia

Burgos, 1495 (día y mes en blanco)

Carta real al contador Juan de Arévalo, contino de la casa real, y a Per Alvarez de la Serna, lugarteniente de contador de la hermandad del reino de Galicia por el obispo de Almería y por Alonso de Quintanilla, ambos del consejo real. Los reyes han ordenado a los contadores mayores de cuentas que tomen las cuentas a Santángel y Pinelo, de sus tesoreros de la Hermandad. Mandan a Arévalo y Álvarez de la Serna que se hagan aclaraciones sobre «descargos» y cuantías de dinero que los tesoreros dicen les deben ser recibidas en cuenta

Los enumeran. Dan plazo para que envíen la relación de todo ello.

Declaración de lo que parece por los libros de la hermandad de Galicia que tiene el contador Juan de Arévalo, contino de la casa de sus altezas, y Pedro Alvarez de la Serna, lugarteniente de contador de la hermandad en el reino de Galicia por los señores obispo de Almería y Alfonso de Quintanilla, del consejo de sus altezas, acerca de las adiciones que fueron puestas en la cuenta de la hermandad de dicho reino de los años 1490, 1491 y 1492:

1. Debe declararse el monto de las deudas de los años anteriores hasta 15 agosto 1489.

Santángel y Pinelo debían cobrar por ellas 3.074 reales

2. Se manda que se envíe razón de los $52.080 \mathrm{mrs}$. que reciben por suspensiones en cada uno de los dichos tres años (enumera las suspensiones, por importe de 5.040 reales $(1.680 \mathrm{al}$ año).

Indica que los vecinos de la villa y tierra del Bollo 'son vasallos de don Juan Pimentel e están encabeçados en la provinçia de Orense'

Siguen otros puntos. Es una minuciosa respuesta a las preguntas planteadas por los contadores mayores sobre diversos aspectos de la cuenta enviada. Entre otros:

3. Explican por qué se libraban cada año $6.608 \mathrm{mrs}$. al herrador de la capitanía (los contadores dicen que no se podía hacer, según las ordenanzas de los reyes). El herrador los cobró por deudas, además de su salario normal anual que, según entiendo, era de $200 \mathrm{mrs}$. por cada lanza de las 70 lanzas y 2 trompetas de que consta la capitanía, a las cuales se les descontaba esta suma de su sueldo ordinario.

4. Justifican el pago de $109.500 \mathrm{mrs}$. dados al licenciado de Roenes, alcalde mayor enviado para residir en el consejo real en este reino de Galicia. Su salario era de 120.000 mrs. anuales. Se le pagaron por salario desde 3 octubre 1492 hasta 31 agosto de 1493. 
3

Hermandad de Galicia. Cargo y data generales de la "sexta prorrogación», de 15 de agosto de 1492 [sic] a 15 de agosto de $1495^{33}$.

(Simancas, CMC leg. 43).

\section{[126] Cargo}

Montó el cargo de la contribución de la hermandad del reino de Galicia de los 3 años, 16 agosto 1492-15 de agosto 1495, según se averiguó con Rodrigo de San Pedro y con los otros receptores que tuvieron cargo por él, en nombre del tesorero Alonso Gutiérrez de Madrid y de Fernando de Villarreal. 18.235 .920

\section{[127] Data}

Se les reciben en libranzas

Restitución del préstamo de 15000 ducados

Alcance

\section{Detalle de la data}

Sumario de gastos de la Hermandad del reino de Galicia, en la 'sexta prorrogación'

[128] Año primero

Sueldo de la capitanía del gobernador don Diego López de Haro 1.231 .372

Acostamientos

Pagas de las tenencias

Salarios 992.498

Libranzas

34.805

Malhechores 15.000

Total 3.860 .708

[129] Año segundo

Sueldo de la capitanía 1.217 .634

Acostamientos

Tenencias 1.096 .388

Salarios... 800.131

Libranzas 47.200

Malhechores 10.000

Total 3.619 .270

\footnotetext{
${ }^{33}$ Este cargo y data forma parte de una «relación sumaria del cargo, data y alcances que parecen por los libros de la Hermandad del Reino de Galicia, que tiene Pedro Álvarez de la Serna por el obispo de Almería y por Alonso de Quintanilla. Por donde se han de tomar y averiguar las cuentas del tesorero Alonso Gutierrez de Madrid, de los cinco años que se cumplieron a 15 de agosto de 1497, del 'cargo de la contribución de la hermandad del dicho reyno", y de los repartimientos de peones de 1495 y de 1496 .
} 
[130] Año tercero

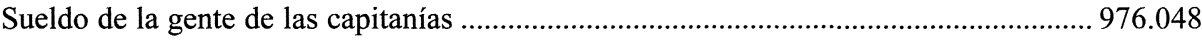

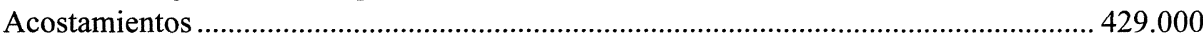

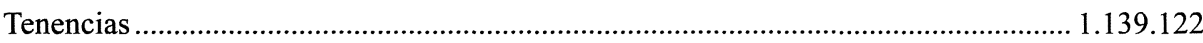

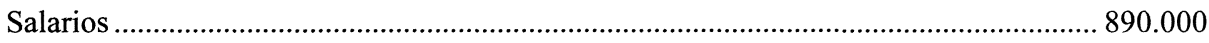

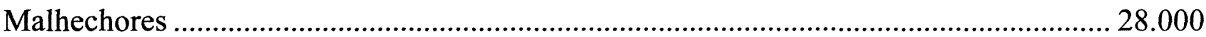

Libranzas, hechas en los tres años ....................................................................... 2.580.684

Sueldo extraordinario, librado fuera de la Ordenanza ................................................. 149.115

Sueldo que se dejó de librar en las nóminas de los años primero y segundo .................... 32.240

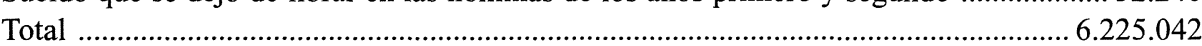

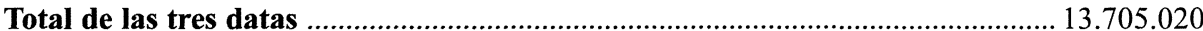

(pero en realidad 'no han de ser más de 13.701 .482 segund lo declararon los contadores de la hermandad del dicho reyno de Galizia').

4

\section{Gastos de la Hermandad de Galicia. Sexta prorrogación}

(Simancas, C.M.C., leg. 43).

\section{Salarios}

(Se indica el salario de dos meses en el año primero de la prorrogación)

131. Don Diego López de Haro, salario por gobernador ...

132. Doctor Luis Niño, maestrescuela de Jaén, del consejo real, alcalde mayor de los reyes en el reino de Galicia

133. Doctor Sancho García del Espinar, del consejo real, alcalde mayor en el dicho reino

134. Doctor del Espinar, por juez ejecutor de la provincia de Segovia ............................. 7.778

135. Doctor Gonzalo Hernandez de Resines, del consejo real y alcalde mayor ...................20.000

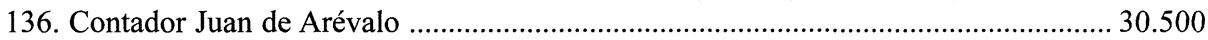

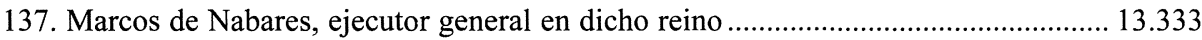

138. Pedro Alvarez de la Serna, contador y oficial ............................................................ 8.333

139. Francisco de Ávila y Garci Sánchez, secretarios del consejo 'del dicho regno de Galizia'

140. Pedro Syso, juez ejecutor prov. Santiago, 5.000 al año, dos meses

141. Bachiller Francisco del Espinar, letrado de los reyes 'para ayudar en los pleitos del dicho oficio'

142. Diego Pérez de Cubrezes, fiscal de sus altezas ............................................................... 250

Total $271.528 \mathrm{~m} .4$ corn

Siguen las datas de las otras pagas bimestrales. Y luego las del año segundo y las del tercero.

143. Los alcaldes de las cinco provincias (Santiago, La Coruña y Betanzos, Mondoñedo, Lugo, Orense) tienen un salario anual de $2.000 \mathrm{~m}$. cada uno 


\section{Sueldos}

Capitania

(Se copia una paga bimestral del año primero)

El gobernador don Diego López de Haro, el capitán don Carlos Enríquez y 37 lanzas de su capitanía por nómina firmada por D. Carlos y por los contadores del reino de Galicia, Juan de Arévalo y Pedro Alvarez de la Serna (Santiago, 2 noviembre 1493)

144. Al gobernador, 'del salario de su persona y del sueldo de las diez lanças de su casa e de los diez peones de su casa'. Sueldo de dos meses ....................................... 91.975

145. Capitán Carlos Enríquez, su sueldo y el de dos lanzas de su casa. Dos meses ......... 17.666

146. Gonzalo Moro, contador de la capitanía, sueldo como una 'lanza doblada'

( 23.570 al año), más por pérdida de caballos, más 10.000 de ayuda de costa por contador. En dos meses son

147. Juan Núñez de Cela, juez ejecutor de la Hermandad de las provincias de La

Coruña y Betanzos, con 5.000 al año de ayuda de costa. Lanza doblada. Dos meses .... 4.145

148. Andrés de Mediano, juez ejecutor de la provincia de Mondoñedo. 20.000

de salario anual. Dos meses

149. Juan de Salcedo, juez ejecutor de la provincia de Lugo, idem. .............................. 3.332,5

150. Juan Muñoz, juez ejecutor de la provincia de Orense, 24.970 al año .......................... 4.145

151. Juan de Haro, alférez de la capitanía, su salario de alférez y su lanza.

26.970 año

152. Fernando de Torquemada, alcaide de la fortaleza de Forelos. Lanza doblada ......... 3.311,5

153. Francisco de Montalvo ....................................................................................... $3.311,5$

154. Martín de Reyno ................................................................................................. 4.139,5

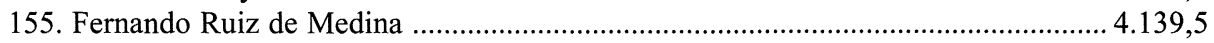

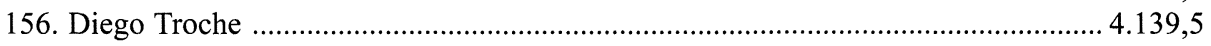

157. Francisco de Montalvo el mozo ……………..................................................... $3.311,5$

158. Diego de Mansilla ............................................................................................ 3.311,5

159. Siguen otras 10 lanzas más ( 4 a 4.139 .5 a 3.311. 1 a 2.500, que es una 'lanza sencilla')

160. Lanzas de Pedro Medrano, a 15.680 por año cada una (2.614,5 el bimestre). Son otras seis (6)

161. Lanzas sencillas a 15.000 por año (2.500 el bimestre). Son otras seis (6) y otras dos (2) a 18.000 el año (3.000 el bimestre)

Según la cuenta, todo lo anterior suma .......................................................233.016,5 mrs

162. Siguen las otras nóminas bimestrales: 198.901.- 395.468 (4 meses).- 192.000.-205.374

163. Año segundo se añaden dos 'tronpetas' a 1.500 al mes cada uno

Total del año

$1.217 .634 \mathrm{~m}$.

164. Año tercero. ..................................................................................... Total ... $976.048 \mathrm{~m}$.

165. Un pliego de la cuenta detalla el «sueldo que se dexó de librar en las nóminas»

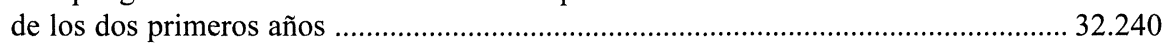

166. Lo mismo para el año tercero ..................................................................... 149.115

\section{Tenencias}

(Se indica el importe de cada tenencia en un cuatrimestre del primer año de la prorrogación)

167. Diego de Valderrábano, alcaide de la fortaleza de Monte Sagro, en al arzob.

Santiago

168. García Sarmiento, alc. Altamira (del conde de Altamira)

12.067

169. Pedro Alvarez de la Serna, alc. Benienço o Buniato (del conde de Altamira) .......... 10.122

170. Juan de Chaves, alc. Riango (del comendador don Enrique Enríquez de Guzmán) ... 10.867

171. Pedro Syso, alc. Peñaflor (de don Hernando de Castro, deán de Santiago) ............... 14.623 
172. Vasco Hernández Noguerol, alc. Sotomayor (del conde de Camiña)

173. Ruy González de Villarroel, alc. Castro de Covdeso (conde de Ribadavia) ............ 16.977

174. Comendador Fernando de Petra, alc. Iglesia y fuerzas de Orense ............................ 29.233

175. García Méndez de Sotomayor, alc. Allariz (de don Juan Pimentel) ......................... 15.767

176. Juan de Montalvo, alc. Los Novaes o Novays ............................................................ 14.566

177. Alonso de Montalvo, alc. Coviel, (del comendador de La Barra de la O. Santiago) . 8.720

(Francisco Ortega en el siguiente cuatrimestre)

178. Pedro Hernández Cabeza de Vaca, alc. Monforte de Lemos (del conde de Lemos) 16.967

(García de Robles en el siguiente cuatrimestre)

179. Alvaro de Villaseñor, alc. Sarria (de los reyes) .......................................................... 33.334

180. Juan Cacho, alc. Los Arcos (conde de Ribadavia) .................................................... 8.720

181. Alonso Ordóñez, alc. del Panbre (del conde don Sancho de Ulloa) ......................... 14.567

182. Francisco Ruiz de Medina, alc. fortaleza de Lugo (del obispo de Lugo) ................. 16.111

183. Capitán don Carlos Enríquez, alc. Tores (de los reyes) .............................................. 13.330

184. Tristán Palomeque, alc. Cervantes (de don Álvaro Osorio) ........................................6.613

(son 39.680 al año. murió en el transcurso de dicho cuatrimestre)

185. Sancho Brizuela, alc. Cervantes desde primero de noviembre

(Juan Montalvo en el siguiente cuatrimestre)

186. Rodrigo de Vallejo, alc. Burol (de don Rodrigo Osorio)

187. Gonzalo Gutiérrez de Çelis, alc. de Castro de Rey (de los reyes) .............................21.666

188. Martín de Durango, alc. fortaleza y fuerzas de Villamayor de Mondoñedo .............. 14.623

189. Alvaro de Torres, alc. Castrodoro (de los reyes) ...................................................... 24.333

190. Pedro de Canseco, alc. Villajuan (de los reyes) ....................................................... 13.226

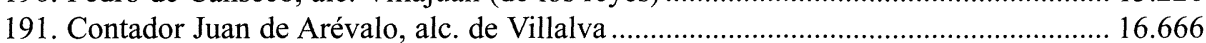

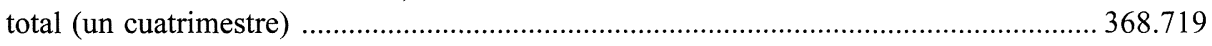

\section{Acostamientos}

(Se indica el importe de cada uno, el primer año de la prorrogación)

192. Pedro Siso, vec. Santiago una lanza «hombre de armas» (h.a.) ...................................... 4.000

193. Ruy García de Linares, vec. Santiago una lanza h.a. .............................................. 4.000

194. Hernando de Montoro, v. La Coruña 2 1. h.a. ............................................................... 8.000

195. Ruy González de Rivadeneyra, v. Vivero, 31 ....................................................... 12.000

196. Vasco López de Rio, v. Coto de San Martino de Mondoñedo, 2 1. ............................ 8.000

197. Pedro Pardo de Cavarros, que es en Mondoñedo, 3 1. ............................................. 12.000

198. Alonso Vázquez de Cavarcos, en el obpdo. Mondoñedo, 2 1.................................... 8.000

199. Sancho López de Rol, v. de Val de Lorenzana, 3 1. ............................................... 12.000

200. Hernando de Goa, v. Val de Lorençana, 1 jinete ...................................................... 3.000

201. Ruy Díaz de las Piñuelas, 'que vive cabe Castro del Rey', una l. ............................. 4.000

202. Pedro de Sayavedra, ‘que vive cabe Castro del Rey', 2 1 .......................................... 8.000

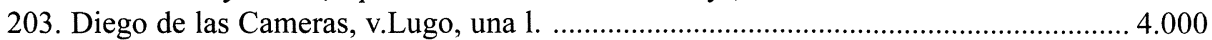

204. Juan Vázquez de Bustelos, 'que vive en Herrera, cabe Pallares', una 1. ..................... 4.000

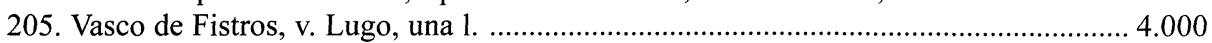

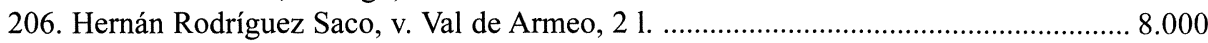

207. Gil Gómez de Cedino ¿, v. La Puebla de Neyra, una 1.............................................. 4.000

208. Gonzalo Núñez Marcado, v. Sarria, una 1. ................................................................... 4.000

209. Gonzalo Pérez Mayordomo, v. Sarria, una 1. ............................................................... 4.000

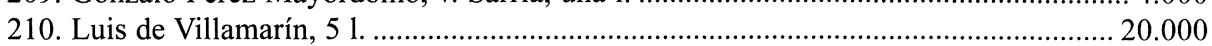

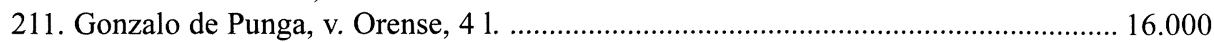

212. Lope de Taboada, que vive en tierra de Canba', 5 1. ................................................. 20.000 
213. Fernando de Canba, 51

214. Vasco Sánchez de Ulloa, v. Pallares, 5 1. (tachado, son 3 1.) ................................... 12.000

215. Frey Alonso, comendador de Puerto Marín, y su hijo Pedro de Páramo, 4 1............ 16.000

216. Herederos de García Rodríguez de Valcárcel, 'cuya es la fortaleza de

tierra de Agostín', 3 l.

217. Herederos de Diego de Lemos, hasta que falleció, 5 1. .............................................. 16.249

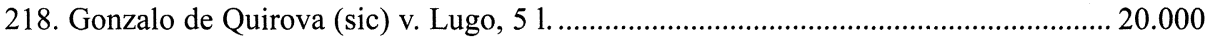

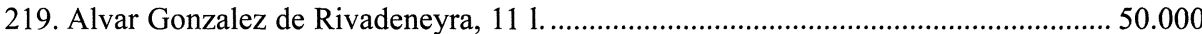

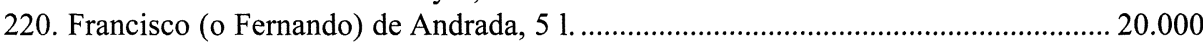

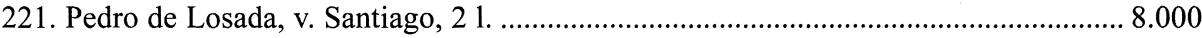

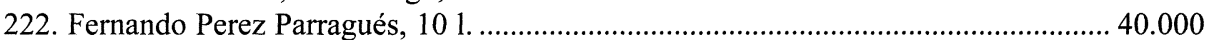

223. Juan Pardo, hermano de Juan Núñez Pardo, una 1.................................................... 4.000

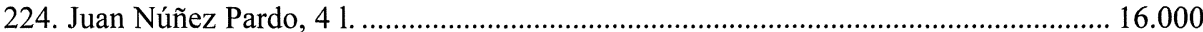

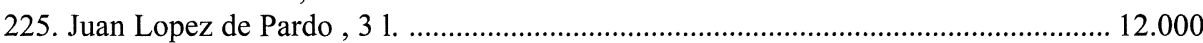

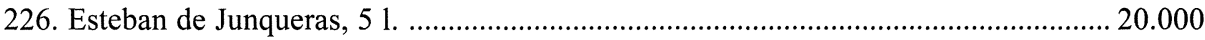

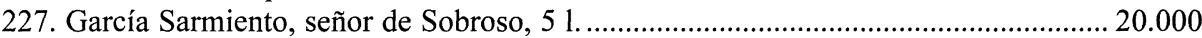

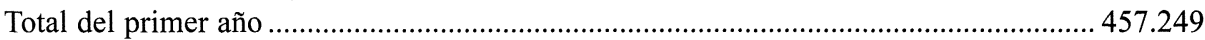

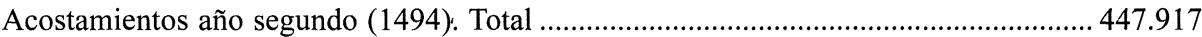

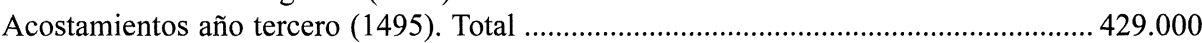

\section{Libranzas}

(Los tres años)

228. Conde de Lemos, por la tenencia de Caldelas de 1 enero a 16 abril 1489 , tres cuartos

229. Al mismo a cuenta del libramiento de un millón que los reyes le mandaron dar "para pagar los daños que se hicieron desde Ponferrada quando estovo cercada» 510.000 230. Diego Sánchez de las Cuentas, v. de $\mathrm{T}^{\mathrm{o}}$, por 1.400 tocinos que pesaron

280 quintales, que dio a Quintanilla y Villalón para la armada de Vizcaya

(20 septiembre 1493)

231. 122.385 gastados en avituallar y pertrechar en el puerto de Muros una nao que era de Pedro Yáñez de Barraca y de Juan de Basarra, vecinos de Muros, «la qual nao se entregó con los dichos pertrechos e bastimentos al comendador Gavriel Valera para las entregar al almirante Christoval Colon para yr a las Yndias» se pagan por orden real y nómina de los contadores del reino de Galicia de Santiago, 9 octubre 1493. Más otros 1.935 del salario de 15 al millar que corresponde a los tesoreros de la Hermandad.

Algunas ayudas de costa ordenadas por los reyes:

232. García Sarmiento, señor de Soboroso, 30.000 en 1495

233. Martin de Reyno, vecino de Sarria, 30.000 en 1495

234. Conde de Ribadeo, 29.000 en 1494. Otros 29.000 en 1495

235. Conde de Monterrey, 100.000 en 1494. Otros 100.000 en 1495

236. Conde de Lemos, por el acuerdo que hicieron los reyes con él de quitarle las $3 / 4$ partes de la Hermandad correspondiente a sus tierras, entre 15 agosto 1492 y 15 agosto 1494

237. Al mismo, para cumplimiento del millón que le libraron los reyes por los daños de Ponferrada

238. Al mismo, por el mismo motivo, otros 100.000

239. Al mismo, por la exención (parcial) de Hermandad de sus tierras entre 1486 y 1492 (el conde era D. Rodrigo Enríquez Osorio). 
240. Obra de la fortaleza de Castro de Oro

241. Obra de cantería en la fortaleza de Sarria

242. Dos baluartes y dos casas para su guarda, hechos en La Coruña por el gobernador 13.800

243. Correos sobre el «armada de Vizcaya que fue con la señora archiduquesa» (aprovisionamientos que se preparan en Galicia)

244. «A Francisco de Noya, correo, por libramiento fecho a X de noviembre de XCV, 30 reales que ovo de aver por yr a la Corte con cartas para Sus Altezas para que sopyesen la muerte del rey de Portogal»

245. Debido de su salario de contino al comendador Hernando de Perea de los años 1495 y parte de 1496 (a 40.000 por año)

246. A Juan Muñoz de Eçela, juez ejecutor de la provincia de Santiago:

19.870 de su salario (lanza doblada) de 1494

9.935 de lo mismo en la primera mitad de 1495

5.000 por juez ejecutor de la provincia de La Coruña y Betanzos

\section{Malhechores}

247. 10.000 de salario a los alcaldes (2000 al de cada provincia)

248. 3.000 a Ruy Domínguez de Villazar, regidor de Bietar (sic) «de su premio porque prendió a Juan Esturiano, que mató un onbre de los frayles del monasterio de Santo Domingo de La Coruña, el qual fue arrastrado y despues asaeteado»

249. 2.000 a Alvaro de la Somoza, «que ovo de aver porque prendió a Pedro vallestero vezino de Loolla, que fue asaeteado porque mató dos onbres con vallesta y no tobo byenes de que pagar el premio»"

250. El año tercero de la sexta prorrogación se pagan 4 libranzas a otros tangos gastos por traer malhechores -ladrones y salteadores- que fueron asaeteados $\ldots 18.000 \mathrm{~m}$. en total

\section{Derechos de tesoreros}

251. Derechos de 10 al millar, del tesorero (además de los 15 al millar), sobre el cargo

total de la contribución de Hermandad de Galicia en los tres años (18.236.000) .... 182.359

\section{5}

"Repartimiento de peones... por vía de Hermandad» en el reino de Galicia.

(Simancas, C.M.C. leg. 43).

\section{Repartimiento}

252. Montó el cargo de repartimiento de los peones que mandaron hacer los reyes en 1495 , $5.400 .000 \mathrm{~m}$., de los que los reyes hicieron merced al reino de Galicia de la tercera parte de esta suma, que se repartió "por los mill peones que el dicho año se repartyeron en Galizia para yr a Seçilia con Alvaro de Torres, e cupieron a razon de setenta e dos maravedíes e dos cornados cada vezino, en çinquenta mill e dies e syete vecinos que se cargaron de paga para en la contribuçion de la Hermandad el dicho año».

Hay que restar también otras «quitas» y «suspensiones», «con algunos maravedies que deven los vezinos que estan en pleito sobre sus hidalguías».

Resta un cargo líquido de $3.560 .184 \mathrm{~m} .4$ cornados 
2. Detalle del repartimiento de peones de 1495 en el reino de Galicia, en las cinco provincias de su Hermandad

253. (Paga cada vecino 72 mrs.y 2 cornados):

$\begin{array}{lr}\text { Provincia } & \text { Vecinos } \\ \text { Santiago con el obispado de Tuy } & 16.060 \\ \text { La Coruña y Betanzos } & 7.524 \\ \text { Mondoñedo } & 3.647 \\ \text { Lugo } & 13.241 \\ \text { Orense } & 9.545 \\ \text { total } & 50.017\end{array}$

Dinero

37.473 reales 10 mrs. 2 corn.

$17.566 \mathrm{r}$.

8.509 r. 20 m. 4 c.

30.895 r. $20 \mathrm{~m} .4 \mathrm{c}$

22.271 r. 20 m. 4 c.

116.706 r. 10 m. 2 c.

254. Suspensiones

El tercio de los 375 vecinos de Santiago y 43 excusados de la obra de su catedral

2 excusados del monasterio de San Martín de Mondoñedo

7 vecinos de Sarria (prov. Lugo)

los 200 vecinos cargados 'a la tierra del Bollo' en la provincia de Orense

Deudas.....

980 reales

Cargo líquido $3.560 .184 \mathrm{~m} .4 \mathrm{c}$

\section{Data}

255. Al capitán Pero Ortiz, «para los bastimentos de la armada que fue con el archiduquesa»

256. Al conde de Ribadeo, por cédula de los reyes . 15.000

257. Tomó el gobernador Diego López de Haro, para el gasto de reparo de la villa de Bayona

258. Pagados, por cédulas reales, al tesorero Alonso de Morales .................................. 2.010.000

259. Se le recibe en cuenta lo que pagó de más en la data de peones 1495-1496, especificada antes de ésta...

260. Salario del tesorero Alonso Gutiérrez de Madrid …............................................. 108.000

261. Se le embargaron, y ahora se le reciben en cuenta ................................................ 102.702

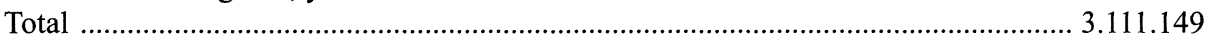

Alcance contra el tesorero 505.045

262. Montan las deudas y suspensiones que se cargaron al gobernador Hernando de Vega (al concluir la hermandad, en 1498, para que las cobrara, supongo)

Hermandad de Galicia. Cargo y data generales de la «séptima prorrogación», de 15 de agosto de 1495 a 15 de agosto de 1498.

(C.M.C., leg. 43)

\section{15 agosto $1495-15$ agosto 1496}

Cargo 6.087 .408

Data

Nómina de los salarios

Nómina del sueldo 
Nóminas de las tenencias

1.084 .765

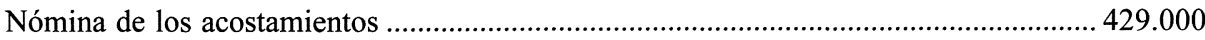

Conde de 'Lemus' por la cuarta parte de sus 'tierras' ...................................................... 100.000

Conde de Monterrey por la cuarta parte de sus 'tierras' ................................................ 100.000

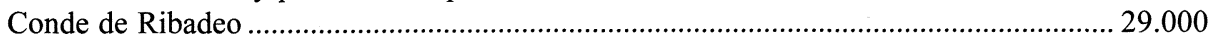

Obras del castillo de Castro de Oro .......................................................................... 70.000

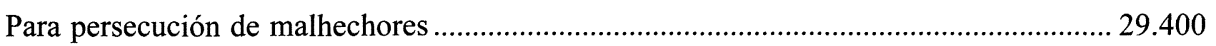

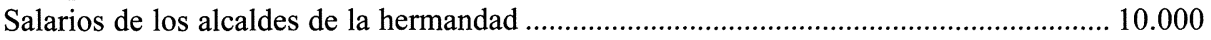

Salario de diez al millar del tesorero, además de los $15 \mathrm{~m}$. que recibe de cada concejo y de los 15 que descuenta a cada persona que paga

Total

\section{15 agosto $1496-15$ agosto 1497}

Cargo 6.050 .000

Data

Salarios

Sueldo

Tenencias

1.095 .965

Acostamientos

429.000

Libranzas extraordinarias ........................................................................................ 337.470

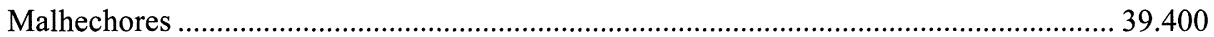

Alcance

\section{15 agosto 1497-15 agosto 1498}

Cargo

Data

Salarios .

Sueldo

Tenencias

1.087 .642

Acostamientos

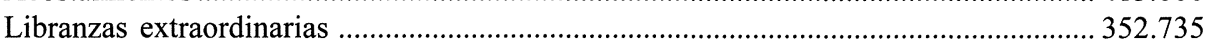

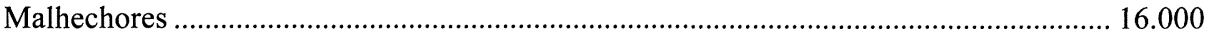

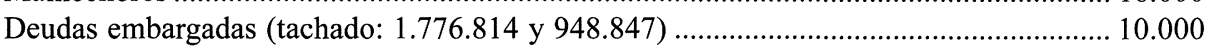

Al tesorero Morales, pagado por Alonso Gutiérrez de Almagro en

nombre de Alonso Gutiérrez de Madrid (tachado 769.837)

$\mathrm{Al}$ tesorero Morales y al contador mayor de cuentas bachiller Serrano

a cuenta de su quitación (tachado 58.129)

total, con lo tachado

total, sin lo tachado

${ }^{34}$ Con este alcance se ha de pagar todo lo que se debe a Diego López de Haro del tiempo que fue gobernador y capitán por sus altezas, hasta que 'fue recibido en los dichos oficios Fernando de Vega'. Son, aproximadamente, $300.000 \mathrm{~m}$.

${ }^{35}$ Estos datos son aproximados y la misma cuenta, en otro lugar, da cifras ligeramente distintas en un resumen del «Cargo general de los dos años» (15 de agosto de 1496 a 15 de agosto de 1498), entregado a los contadores mayores de cuentas en Granada, a 9 de octubre de 1499. Dicho cargo 
Gastos de la Hermandad de Galicia en el bienio 15 agosto 1496 a 15 agosto 1498.

(C.M.C., leg. 43$)$.

\section{Salarios}

(Se indica el importe de dos meses del primer año)

266. Gobernador don Diego López de Haro (200.000 al año) .....

(desde noviembre de 1496 baja su salario a 133.333 por orden de los reyes)

Parece que en enero de 1497 ya había cesado, puesto que no se le incluye en la nómina de enerofebrero. El 12 de abril de 1497 «fue recibido» por gobernador y comenzó a cobrar su salario Hernando de Vega. (100.000 al año para él, y 72.000 para diez peones de su escolta)

Son 28.666 cada dos meses.

De todos modos, hay otro asiento de 100.000 mrs. a favor de don Diego López de Haro, de su salario desde 1 de enero de 1497 en adelante.

267. Además, en 1497 se paga a don Carlos Enríquez de Cisneros, corregidor de las ciudades de La Coruña y Betanzos, con dos lanzas sencillas a su servicio (integradas en la capitanía del gobernador)

(El resto permanece igual en el primer año de la prorrogación. Salarios de dos meses):

268. Doctor Gonzalo Martínez de Villovela, del Consejo del reino de Galicia ................20.000

269. Licenciado Diego Martínez de Astudillo, idem ...................................................... 20.000

270. Licenciado Sancho de Frías, alcalde mayor y del consejo ........................................20.000

271. Juan de Arévalo, contador de los reyes en dicho reino (500 m. al día) ........................ 30.500

272. Marcos de Nabares, ejecutor general de la Hermandad en el reino de

Galicia (80.000 al año)

273. Gil Nieto, contador de la capitanía de D. Diego López de Haro (10.000 al año) ....... 1.666

274. Pedro Alvarez de la Serna, contador de la Hermandad de Galicia (50.000 al año) $8.333 \mathrm{~m} .2 \mathrm{c}$

275. Bachiller Francisco del Espinar y Diego Pérez de Cobreces, letrado y

fiscal de sus altezas en Galicia (6.000 al año el letrado, 2.000 el fiscal)

276. Pedro Muñoz y Cristóbal Mejía, secretarios del Consejo de Galicia (10.000

al año cada uno)

(5iso, juez ejecutor Hermandad, provincia Santiago (5.000 al año) _..... 8332 c.

278. Juan Núñez Pardo de Cela, idem. prov. La Coruña y Betanzos ..................................... 833

279. Diego de Mansilla, idem. prov. Mondoñedo ………........................................................... 833

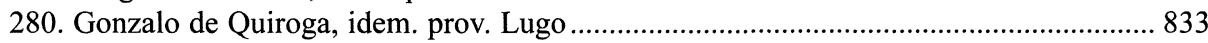

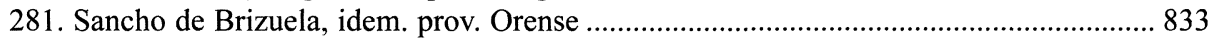

Data del año segundo de la séptima prorrogación (agosto 1497-agosto 1498). Salarios ordinarios:

282. El gobernador es ya Hernando de Vega (100.000 al año por la gobernación y 72.000 para diez peones)

asciende a $12.402 .500 \mathrm{mrs}$. (la mitad cada año. 128 reales más el primero de ambos). Deudas y suspensiones: 1496-1497: $110.608 \mathrm{mrs}$ - 1497-1498: $1.018 .736 \mathrm{mrs}$. (esta última partida viene acompañada por una 'relación de la cuenta del gobernador Hernando de Vega, de las debdas que fueron a su cargo de cobrar', y que son efectivamente las de 1497-1498: $1.018 .736 \mathrm{mrs}$.). 
283. Doctor Gonzalo Martínez de Villovela, alcalde mayor y del consejo del reino de Galicia 284. Licenciado Diego Martínez de Astudillo, alcalde mayor y del consejo

285. Licenciado Alonso Maldonado, alcalde mayor y del consejo

286. Contador Juan de Arévalo, contador en el dicho reino

287. Pedro Alvarez de la Serna, contador en el dicho reino

288. Gil Nieto, contador de la gente que estuvo en dicho reino con el consejo

289. Bachiller Luis de Soto, letrado del consejo

290. Cristóbal Mexía y Pedro Muñoz de Córdoba, secretarios del consejo

291. Pedro Siso, juez ejecutor de la Hermandad en la provincia de Santiago

292. Juan Núñez Pardo de Çela, juez ejecutor de la provincia de La Coruña y Betanzos

293. Diego de Mansilla, juez ejecutor de la provincia de Mondoñedo

294. Gonzalo de Quiroga, juez ejecutor de la provincia de Lugo

295. Sancho de Brizuela, juez ejecutor de la provincia de Orense

Total de salarios ordinarios en todo el año

\section{Sueldos}

«Del governador del dicho reyno y de la gente de su capytanía». Se indica el sueldo de dos meses.

296. El gobernador don Diego López de Haro tiene 200.000 al año, por el cargo de capitán, más 169.480 para sueldo de «diez lanças de su casa», 4 de ellas «dobladas» (19.870 al año cada una) y 6 «sencillas» ( 15.000 al año cada una), más otros 72.000 para sueldo de 10 «peones de su casa» (a 7.200 al año cada uno)

Monta todo ello en dos meses 73.580

(desde la segunda paga cobra ya «al respecto» de 133.333 al año ... 56.466)

297. El nuevo gobernador, Hernando de Vega, sólo tenía sueldo para 5 lanzas dobladas (desde el 12 de marzo de 1497 comienzan a cobrar. A $19.870 \mathrm{~m}$. al año cada una. Una de ellas es alférez y tiene 7.000 más al año) Son 17.578 m. 2 c. cada dos meses

298. Tres regidores de La Coruña, a 10.000 al año cada uno: Lope Díaz Peynero, Pedro de Montoro, Jácome Colmelo.

Estos desaparecen de las pagas a partir de enero de 1497 (¿por la llegada del nuevo corregidor?) 299. Desde enero de 1497 figura ya el corregidor de La Coruña y Betanzos, don Carlos Enríquez de Cisneros, con $106.000 \mathrm{~m}$. al año, 'non enbargante que toviese los dichos ofiçios de corregimientos', para su persona y para dos lanzas sencillas que había de tener en dicha capitanía. Son $17.664 \mathrm{~m}$. cada dos meses

300. Gil Nieto, contador de la capitanía (19.870 al año) $3.311 \mathrm{~m} .4 \mathrm{c}$.

301. Diego de Mansilla, juez ejecutor Hermandad prov. Mondoñedo. 1 lanza d... 3.311 m. 4 c.

302. Otras 10 lanzas 'dobladas' más a $3.311 \mathrm{~m} .4$ corn. cada una

303. 10 lanzas sencillas a 15.680 al año. Dos meses ... $2.613 \mathrm{~m}$. 2 corn. cada una (entre ellas Sancho de Brizuela, juez ejec. prov. Orense)

304. 8 lanzas sencillas 15.000 al año. Dos meses ... 2.500 cada una (entre ellas Gonzalo de Quiroga, juez. ejec. prov. Lugo)

305. 2 trompetas, a 18.000 al año cada uno

Esta distribución apenas varia en 1497, pero se observa que las lanzas dobladas son entre $10 \mathrm{y}$ 12 , las sencillas de 15.680 son entre 9 y 11 , y las de 15.000 , otras 5 a 8 . Hay algunos cambios de personas por los que 'se despidieron' y los que 'asentaron' en lugar de ellos. 
Sueldo. Data del año segundo de la séptima prorrogación de la Hermandad (agosto 1497agosto 1498):

306. El gobernador tiene 5 lanzas dobladas (además de las de la capitanía destacada en el reino) 307. Alvaro Vázquez, alférez, $7.000 \mathrm{al}$ año

308. Don Carlos Enriquez de Cisneros, corregidor de La Coruña y Betanzos, con dos lanzas sencillas $106.000 \mathrm{mrs}$. al año 309. Juan Núñez Pardo de Cela, juez ejecutor, cobra además como lanza doblada en la capitanía (19.870 m. al año)

310. Gil Nieto, contador de la capitanía, cobra como lanza doblada (19.870 m/año)

311. Otras 11 lanzas dobladas

312. 11 lanzas sencillas (a 15.680 al año)

313. 7 lanzas sencillas más (a 15.000 al año)

314. 2 trompetas (a 18.000 al año cada uno)

\section{Tenencias}

(Pago del último cuatrimestre de 1496. El nombre de la fortaleza entre /.. /):

315. Vasco Hernández Noguerol, alc. Altamira, con una lanza d. y 6 peones ................... 12.166

316. Diego de Valderravano, alcaide de Montesagro, una lanza senc. y 4 p. .................... 11.626

317. Pedro Sarmiento, alc. Benianço, una 1.d. 5 p. ......................................................... 10.967

318. Luis de Villarroel / Rianjo/, una 1.d., 5 p. ................................................................. 14.623

319. Pedro Siso /Peñaflor/ una 1.d., 5 p......................................................................... 14.623

320. Diego Troche / Sotomayor / una 1.d., 7 p. (a 4.800 al año cada peón) ....................... 16.406

(le sucede Diego López de Angulo)

321. Ruy González de Villarroel / Castro de Covadoso / una 1.d., 10 p. .......................... 22.623

322. Juan de Haro /fuerzas Iglesia Orense/ una l., 10 p. .................................................. 22.623

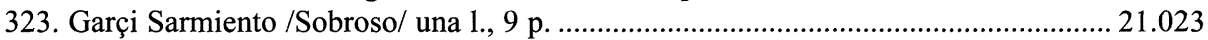

324. Juan de Montalvo /Los Navares/, una 1.d., 8 p. ...................................................... 14.522

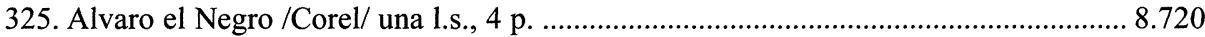

326. García de Robles /Monforte de Lemos/ una 1.d., 10 p ............................................. 16.967

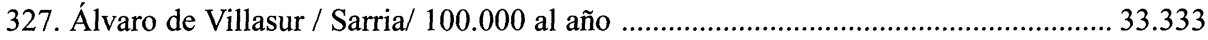

328. Francisco Ortega /Los Arcos/ una 1.d., 4 p. ........................................................... 13.023

329. Alonso Ordóñez /Panbre/ y JuanVarela, su lugarteniente. una 1.d., 8 p. ................... 14.567

330. Francisco Ruiz de Medina / Lugo /, una 1.d., 8 p. ................................................. 19.422

331. Don Carlos Enríquez de Cisneros / Tores / ............................................................... 11.200

332. Pedro Núñez de Guzmán y Álvaro de Valderas, su alcaide de Cervantes, 5 p. ..........8.000

333. Martín de Durango /Burón/, una 1.d., 6 p............................................... 16.223 m. 2 c.

334. Gonzalo Gutiérrez de Çelis, hijo de Gonzalo Hernández de Çelis /Castro de Rey/21.666 4 c.

335. Álvaro de Torres /Castro doro/, una l.d., 7 p. ..................................................... 24.333

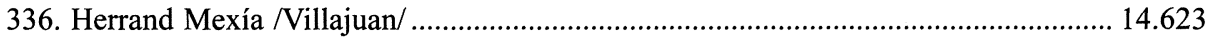

337. Juan Núñez Pardo de Cela, para una 1.d. y 7 p. …................................................. 17.823

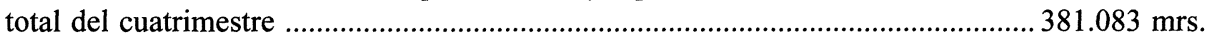

(tercio segundo, 369.252. último tercio, 334.430. Total del año ... 1.095.965)

338. en el último tercio han desaparecido Hernán Mexía (Villajuan) y Diego Troche (Sotomayor)

Tenencias en el último cuatrimestre de 1497:

339. Vasco Hernández Noguerol, alc. Altamira, con una lanza doblada y 6 peones (paga la cuarta parte el conde de Altamira. El resto los reyes)

340. Diego de Valderrábano, alc. Montesagro, una lanza sencilla y 4 peones 
341. Pedro Sarmiento, alc. Benianço, una 1. doblada y 5 peones.

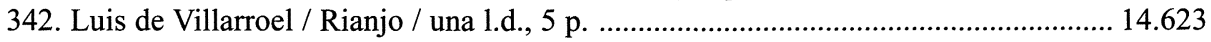

343. Pedro Siso /Peñaflor/ una 1.d., 5 p. .......................................................................... 14.623

344. Ruy Gomez o Gonzalez de Villarroel, una l.d., 10 p................................................ 22.623

345. Juan de Haro / 'fuerças de la yglesia de Orense' / una 1.d., 10 p. ............................. 22.623

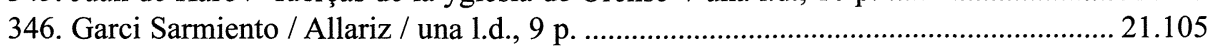

347. Juan de Montalvo / Los Novaes 'que es en Quiroga'/ una 1.d., 8 p. ........................ 14.520

348. Alvaro o Alonso el Moro / Corel / una 1.sencilla, 4 p. ............................................... 8.720

349. García de Robres / Monforte de Lemos / una l.d., 10 p. ........................................ 16.967

350. Alvaro o Alonso de Villasur / Sarria / ................................................................. 33.333,3

351. Francisco Ortega / Los Arcos / una l.d., 4 p. .......................................................... 13.023

352. Francisco Ruiz de Medina /Lugo / una 1.d., 8 p. ........................................................ 19.422

353. Don Carlos Enríquez de Cisneros / Tores / ............................................................ 11.200

354. Pedro Núñez de Guzmán / Çervantes / y en su nombre a Alvaro de Valderas ............ 8.000

355. Martín de Durango / Burón / una 1.d., 6 p............................................................. 16.223

356. Gonzalo Gutierrez de Çelis / Castro de Rey / ...........................................................21.666

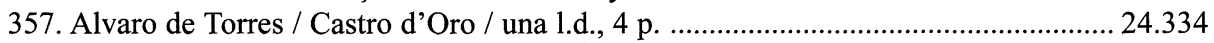

358. Juan Núñez Pardo de Cela / Villalva / .................................................................. 16.666

359. Ferrand Çeron, corregidor de Mondoñedo, /'alcaide de las fuerças de la yglesia

de Villa Mayor de Mondoñedo» / 5 p. ...................................................................... 8.000

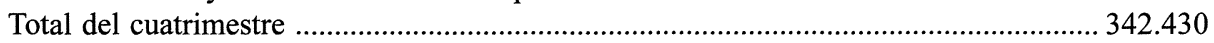

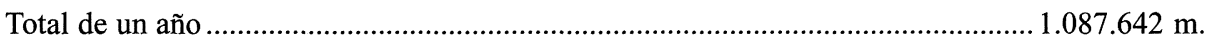

\section{Acostamientos}

(El gasto de un año asciende a $429.000 \mathrm{~m}$.. Son 33 personas. Se entiende que las 'lanzas' son 'hombres de armas', si no se indica otra cosa. Cuando alguién recibe pago por varias 'lanzas', una es él mismo).

360. Pedro Siso, vecino y regidor de Santiago (además de otra lanza de su persona en

la capitanía del gobernador), una lanza « hombre de armas a la bastarda». 4.000

361. Ruy González de Linares, v. Santiago, una 1. h.a. ..................................................4.000

362. Martín de Reino, v. Santiago, 2 1. (sirve con otra en la capitanía) ............................. 8.000

363. Pedro de Losada, v. Noya, 2 1. (sirve con otra en la capitanía) .................................... 8.000

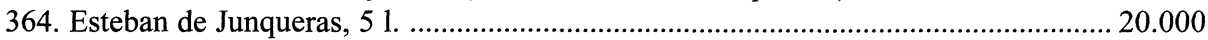

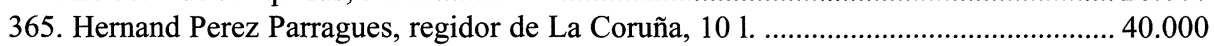

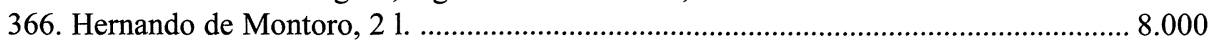

367. Juan López de Villausaz, v. y regidor de Betanzos, 3 1. ........................................ 12.000

368. Juan Núñez Pardo de Cela, v. Betanzos, 5 1. (más 'de su lança que sirve en la

dicha capitanía') ................................................................................................... 20.000

369. Juan Pardo, hermano del anterior, v. Betanzos, una 1............................................ 4.000

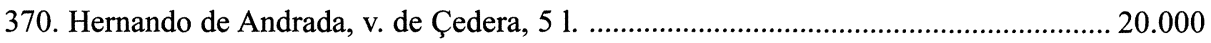

371. Ruy González de Ribadeneyra, v. Vivero, 31 .................................................... 12.000

372. Vasco López de Río, 'morador en el coto de Sant Martino de Mondoñedo', 2 1. ......8.000

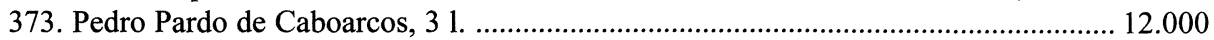

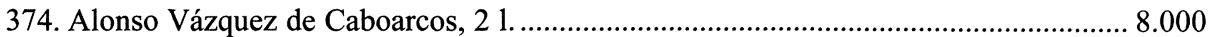

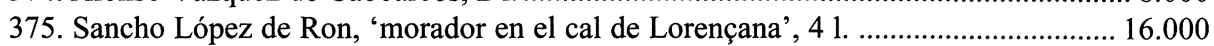

376. Hernando de Gua, v. Lorenzana, una 1. 'a la gineta' ................................................ 3.000

377. Ruy Díaz de las Pynelas, 'morador en Las Pynelas çerca de Castro del Rey', una lanza 'a la bastarda' 


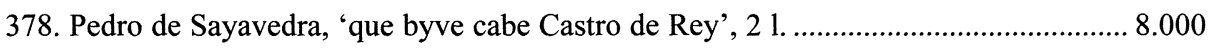

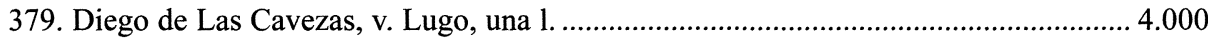

380. Juan Vázquez de Bustelo, v. Herrera de Negral, una 1. ............................................... 4.000

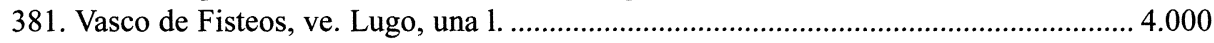

382. Gil Gómez de Çedro, v. La Puebla de Neyra, una 1................................................. 4.000

383. Gonzalo Pérez, v. Sarria, una 1................................................................................ 4.000

384. Alvar González de Ribadeneyra, 10.000 para su persona, 40.000 para 101 1.......... 50.000

385. Gonzalo de Quiroga, 4 l. (sirve otra en la capitanía) ................................................ 16.000

386. Fray Alvaro de Quiroga, comendador de Puertomarín, y Pedro de Páramo,

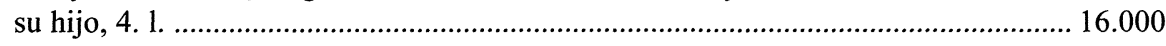

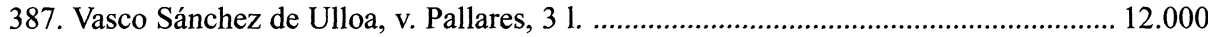

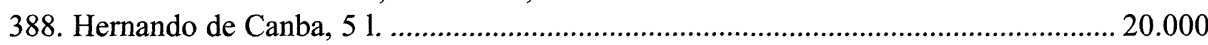

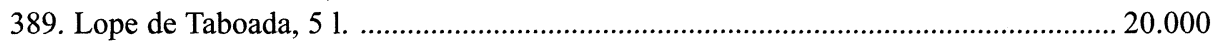

390. Luis de Villamarín, ‘cuya es Villamarín', 5 1 ...................................................... 20.000

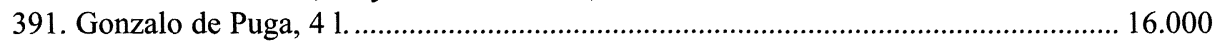

392. Garçi Sarmiento, ‘cuya es Sobroso', 5 1. .............................................................. 20.000

Año segundo de la séptima prorrogación:

393. Acostamientos. Pago de un año .......................................................................... 413.000

Son 32 personas

1 sirve con una lanza jineta.- 9 con 1 lanza doblada, cada una.- 6 con 2 lanzas dobladas.- 4 con

3 lanzas dobladas.- 3 con 4 lanzas dobladas.- 7 con 5 lanzas dobladas.-

Hernán Perez Parragues, vecino y regidor de La Coruña, con 10 lanzas (40.000).

Alvar Gonzalez de Ribadeneyra, 'cuya es La Barrera', con 10 lanzas (40.000 más otros 10.000 'para su persona').

\section{Libranzas extraordinarias}

Año primero de la séptima prorrogación:

394. Juan Núñez Pardo de Cela, que se le debía de su oficio de juez ejecutor de la provincia de La Coruña y Betanzos, alcaide de Villalva, y por la lanza doblada que tiene en la capitanía del gobernador

28.378 más otros 6.623 (en total tenía que cobrar 120.763 m., de los que 50.000 corresponden a su tenencia)

395. Don Rodrigo Enríquez Osorio, conde de Lemos, «por la quarta parte de la

Hermandad de las tierras del dicho conde» ........................................................... 100.000

396. Don Sancho de Ulloa, conde de Monterrey, de merced real .................................... 100.000

397. Don Pedro de Villandrando, conde de Ribadeo, de merced real ............................... 29.000

398. Obras en el castillo de Montedoro (a los maestros canteros Rodrigo de Hoz y

Ruy Vizcaino, que las tomaron a destajo) ............................................................ 70.000

399. Se reciben en cuenta al tesorero por diversos conceptos cantidades menores:

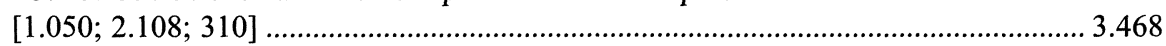

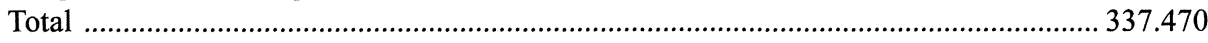

Año segundo de la séptima prorrogación. Libranzas extraordinarias:

400. Conde de Lemos, «por la cuarta parte de la Hermandad de sus tierras» ................. 100.000

401. Conde de Monterrey, don Sancho de Ulloa, por merced real ................................. 100.000

402. Don Pedro de Villandrando, conde de Ribadeo, en la hermandad de su tierra ......... 29.000 
403. «Honrras e obsequias que se hizieron en la çibdad de Santiago el año de XCVII por el prinçipe nuestro señor que santa gloria aya»

404. Juan de Moscoso, por ir a «çiertas partes» con cartas del gobernador y del consejo .... 800

\section{Persecución de malhechores}

405. Se libran a dos alcaldes de Hermandad en cada una de las cinco provincias, 1.000 10.000

Premios a captores de malhechores (se les da si no tienen bienes los malhechores de que pagar estos premios). 39.400 m. en total. Reparto:

406. Ruy López, alcalde de la hermandad de Herreros, en el arzobispado de Santiago, por prender a Juan de Moscoso, ladrón, y Juan Çebollino, 'de los que fue hecha justicia'.

407. Gonçalo de Lodero, porque prendió a Alvaro del Monte, que fue asaeteado .............. 3.000

408. Ruy González de Villarroel, alcaide de Castro de Covadoso, por prender a Jorge de Deça y Vasco Alfay, malhechores, asaeteados

409. Diego de Valderrábano, alcaide de Montẹsagro, por prender a Vasco de Rel, malhechor, asaeteado

410. Diego de Laguna, escudero de la capitanía del Gobernador, por prender a dos malhechores, uno azotado y el otro desterrado

411. Licenciado Esteban Suárez, alcalde mayor de las tierras de don Juan Pimentel, por prender a Gómez de Corel, malhechor, asaeteado

412. Diego López de Villavriz, merino del conde don Sancho de Ulloa, por prender a Rodrigo de Mijonfrío, «salteador de caminos, e por las costas que hizo en lo llevar preso a Orense e en lo llevar al camino francés, donde fue asaeteado»

413. Gonzalo Ballestero, que «se halló» con el anterior en la prisión de dicho salteador. El gobernador y los alcaldes mayores se lo mandaron dar «para se vestir en albriçias de la dicha prisión e por lo que en ello trabajó»

414. Broz Pardo, por prender a Rodrigo de Ansian, malhechor, asaeteado …..................... 3.000

415. Alonso de Baeça, alcalde, por prender a un malhechor «de que fue hecha justicia» .... 1.500

Año segundo de la séptima prorrogación:

416. A los alcaldes de las 5 provincias

417. Dos premios de 3.000 a sendos apresadores de malhechores que fueron asaeteados «e no tenya bienes» el malhechor con qué pagar el premio.

\section{Derechos de tesoreros}

Derechos de diez al millar del tesorero de los dos años de la séptima prorrogación ..... 112.735 


\section{ÍNDICE DE PERSONAS ${ }^{36}$}

\section{A}

Alfay, Vasco; 408.

Alonso, fr., v. Quiroga, Álvaro de.

Alonso (o Álvaro), el Moro, v. Álvaro, el Moro.

Alvarez, Alonso; 8.

Alvarez de la Puebla del Burullón, Rodrigo; 91.

Alvarez de la Serna, Pedro; 1 (Ordenanza real de 1491), 7, 125, 3 (Hermandad de Galicia. Sexta prorrogación de 15 de agosto de 1492, nota 31), 138, 4 (Gastos de la Hermandad de Galicia. Sexta prorrogación), 169, 274, 287.

Alvarez de la Serna, Per, v. Álvarez de la Serna, Pedro.

Álvaro, el Negro; 325.

Andrada, Fernando o Francisco; 220. .

Andrada, Hernando; 370.

Ansian, Rodrigo de; 414.

Arévalo, Juan de; 1 (Ordenanza real de 1491), 6, 30, 31, 51, 67, 116, 125, 136, 4 (Gastos de la Hermandad de Galicia. Sexta prorrogación), 191, 286

Armesto, Arias de; 46.

Ávila, Francisco de; 8, 139.

\section{B}

Baeça, Alonso de; 415.

Ballestero, Gonzalo; 413.

Basarra, Juan de; 231.

Brizuela, Sancho de; 185, 281, 295, 303.

C

Caboarcos, v. Pardo de Caboarcos y Vázquez de Caboarcos.

Cacho, Juan; 180.

Cameras, Diego de las; 203.

Canba, Fernando de; 213, 388.

Canba, Hernando de; v. Canba, Fernando de.

Canseco, Pedro de; 190.

Castro, Hernando de; 171.

Cavezas, Diego de Las; 379.

Çebollino, Juan; 406.

Çerón, Ferrand; 359.
Chaves, Juan de; 170

Chillón, Juan de; 39.

Cisneros, Carlos de, v. Enríquez de Cisneros, Carlos.

Cobreces, v. Pérez de Cobreces.

Colmelo, Jácome; 298.

Coloma, Juan de; 1 (Ordenanza real de 1491).

Colón, Christoval; 231.

Corel, Gómez de; 411.

Cornejo, Antonio; 5, 40, 94.

\section{D}

Deça, Jorge de; 408.

Díaz Peynero, Lope; 298.

Díaz de las Pynelas, Ruy; 201, 377.

Díaz de las Piñuelas, Ruy, v. Díaz de las Pynelas, Ruy.

Díez de Tablares, Ruy; 62.

Domínguez de Villazar, Ruy; 248.

Durango, Martín de; 188, 333, 355.

E

Enríquez, Alonso; 89.

Enríquez de Cisneros, Carlos; 12 , 15, 16, 17 , $34,40,51,67,105,106,4$ (Gastos de la Hermandad de Galicia. Sexta prorrogación), 145, 183, 267, 299, 308, 331, 353.

Enríquez de Guzmán, Enrique; 170.

Enríquez Osorio, Rodrigo; 57, 239, 395.

Espinar, doctor, v. García del Espinar, Sancho.

Espinar, Francisco del; 141, 275.

Esturiano, Juan; 248.

\section{F}

Fisteos, Vasco de; 205, 381.

Fistros, Vasco de, v. Fisteos, Vasco de.

Frías, Sancho de; 270.

G

García del Espinar, Sancho; 3, 4, 40, 54, 133, 134.

García de Linares, Ruy; 193.

\footnotetext{
${ }^{36}$ Los índices de personas y lugares han sido elaborados por Carlos Andrés González de Paz.
} 
Goa, Hernando de; 200, 376.

Gómez de Çedro, Gil, v. Gómez de Çedino, Gil. Gómez de Çedino, Gil; 207, 382.

González de Linares, Ruy; 361.

Gonzalez de Rivadeneira, Alvar; 24, 219, 384, 393.

González de Rivadeneyra, Alvar, v. González de Rivadeneira, Alvar.

González de Ribadeneyra, Ruy, v. González de Rivadeneyra, Ruy.

González de Rivadeneyra, Ruy; 195, 371.

González (o Gómez) de Villarroel, Ruy; 173, $321,344,408$.

Gua, Hernando de, v. Goa, Hernando de. Gutiérrez de Almagro, Alonso; 265.

Gutiérrez de Çelis, Gonzalo; 22, 187, 334, 356.

Gutiérrez de Madrid, Alonso; 126, 3. (Hermandad de Galicia. Sexta prorrogación de 15 de agosto de 1492, nota 31), 260, 265.

\section{H}

Haro, Juan de; 151, 322, 345.

Hernández Cabeza de Vaca, Pedro; 178.

Hernández de Çelis, Gonzalo; 334.

Hernández Noguerol, Vasco; 172, 315, 339.

Hernandez de Resines, Gonzalo; 135.

Herrán, Pedro; 92.

Hoz, Rodrigo de; 398.

\section{J}

Junqueras, Esteban de; 226, 364.

L

Laguna, Diego de; 410.

Ledesma, Pedro de; 90 .

Lemos, Diego de; 217.

Lodero, Gonçalo de; 407.

López, Ruy; 406.

López de Angulo, Diego; 320.

López de Haro, Diego; 1 (Ordenanza real de 1491), 1, 11, 29, 30, 31, 128, 131, 4 (Gastos de la Hermandad de Galicia. Sexta prorrogación), 257, 263 (nota 32), 266, 273, 296.

López de Pardo, Juan; 225.

López de Río, Vasco; 196, 372.

López de Rol, Sancho, v. López de Ron, Sancho.

López de Ron, Sancho; 199, 375.

López de Villausaz, Juan, 367.
López de Villavriz, Diego; 412.

Losa, Pedro de; 118.

Losada, Pedro de; 221, 363.

\section{M}

Madrid, Lorenzo de; 122.

Maldonado, Alonso; 285.

Mansilla, Diego de; 158, 279, 293, 301.

Martínez de Astudillo, Diego; 269, 284.

Martínez Pardo de Cela, Juan; 77.

Martínez de Villovela, Gonzalo; 268, 283.

Mediano, Andrés de; 148.

Medrano, Pedro; 160

Mejía, Cristóbal; 276, 290

Méndez de Sotomayor, García; 175.

Mexía, Cristóbal, v. Mejía, Cristóbal.

Mexía, Hernán, v. Mexía, Herrand.

Mexía, Herrand; 336, 338.

Mijonfrío, Rodrigo de; 412.

Mondin, Pedro de; 90.

Montalvo, Alonso de; 177.

Montalvo, Francisco de; 153.

Montalvo, Francisco de (el mozo); 157.

Montalvo, Juan (de); 176, 185, 324, 347.

Monte, Alvaro del; 407.

Montoro, Hernando de; 194, 366.

Montoro, Pedro de; 298.

Morales, Alonso de; 258, 265.

Moro, Gonzalo; 1 (Ordenanza real de 1491), 13, 70, 146.

Moscoso, Juan de; 404.

Moscoso, Juan de; 406.

Muñoz, Juan; 150.

Muñoz, Pedro, v. Muñoz de Córdoba, Pedro.

Muñoz de Córdoba, Pedro; 276, 290.

Muñoz de Eçela, Juan; 246.

\section{$\mathbf{N}$}

Nabares, Marcos de, v. Navares, Marcos de.

Navares, Marcos de; 9, 137, 272.

Nieto, Gil; 273, 288, 300, 310

Niño, Luis; $96,132$.

Noya, Francisco de; 244.

Núñez, Juan; 111.

Nuñez de Cela, Juan; 117, 147.

Núñez Coronel, Fernán; 30, 61.

Nuñez de Guzmán, Pedro; 332, 354.

Nuñez Marcado, Gonzalo; 208.

Nuñez Pardo, Juan; 223, 224. 
Núñez Pardo de Cela, Juan; 278, 292, 309, 337 , 358, 368, 394.

Nuñez Pardo de Çela, Juan, v. Núñez Pardo de Cela, Juan.

\section{O}

Ordóñez, Alonso; 181, 329.

Ortega, Francisco; 177, 328, 351.

Ortiz, Pero; 255.

Osorio, Álvaro; 184.

Osorio, Rodrigo; 186.

\section{$\mathbf{P}$}

Palomeque, Tristán; 184.

Páramo, Pedro de; 215, 386.

Pardo, Broz; 414.

Pardo, Juan; 111, 223, 369.

Pardo de Caboarcos, Pedro; 197, 373.

Pardo de Cavarros, Pedro, v. Pardo de Caboarcos, Pedro.

Pardo de Cela, v. Martínez Pardo de Cela y Núñez Pardo de Cela.

Pedro; 249.

Perea, Fernando de; 20, 245.

Perea, Hernando de, v. Perea, Fernando de.

Pérez, Gonzalo, v. Pérez Mayordomo, Gonzalo.

Pérez de Cobreces, Diego, v. Pérez de Cubrezes.

Pérez de Cubrezes, Diego; 142, 275.

Pérez Mayordomo, Gonzalo; 209, 383.

Pérez Parragués, Fernán, v. Pérez Parragués, Fernando.

Pérez Parragués, Fernando; 51, 52, 115, 222 , 365, 393.

Pérez Parragués, Hernán, v. Pérez Parragués, Fernando.

Pérez Parragués, Hernand, v. Pérez Parragués, Fernando.

Pérez Parragués, Hernando; v. Pérez Parragués, Fernando.

Petra, Fernando de; 174.

Pimentel, Juan; 125, 175, 411.

Pinelo, Francisco; 26, 125.

Puga, Gonzalo de; 211, 391.

Punga, Gonzalo de, v. Puga, Gonzalo de.
Q

Quintanilla, Alfonso de; 1 (Ordenanza real de 1491), 125, 128 (nota 31), 230.

Quintanilla, Alonso de, v. Quintanilla, Alfonso de.

Quiroga, Álvaro de; 215, 386.

Quiroga, Gonzalo de; 218, 280, 294, 304, 385.

Quirova, Gonzalo de, v. Quiroga, Gonzalo de.

\section{$\mathbf{R}$}

Reino, Martín de; 120, 154, 233, 362.

Reinoso, Diego de; 102.

Rel, Vasco de; 409.

Reyno, Martín de, v. Reino, Martín de.

Robles, García de; 178, 326, 349.

Robres, García de, v. Robles, García de.

Rodríguez Saco, Hernán; 206.

Rodríguez de Valcárcel, García; 216.

Roenes; 125.

Ruiz de Medina, Fernando; 155.

Ruiz de Medina, Francisco; 182, 330, 352.

\section{$\mathbf{S}$}

Salazar, Alonso de; 60.

Salcedo, Juan de; 56, 149.

Sánchez, Garci; 139.

Sánchez de las Cuentas, Diego; 230.

Sánchez de Ulloa, Vasco; 214, 387.

San Pedro, Rodrigo de; 126.

Santángel, Luis de; 2 (Cuenta de la quinta prorrogación), 26, 125.

Sarmiento, Garçí, v. Sarmiento, García.

Sarmiento, Garci, v. Sarmiento, García.

Sarmiento, García; 168, 227, 232, 323, 346, 392.

Sarmiento, Pedro; 317, 341.

Sayavedra, Pedro de; 202, 378

Sayvedra, Pedro de, v. Sayavedra, Pedro de.

Serna, v. Ávarez de la Serna.

Serrano; 265.

Siso, Pedro; 85, 140, 171, 192, 277, 291, 319 , 343, 360.

Syso, Pedro, v. Siso, Pedro.

Somoza, Álvaro de la; 249.

Soto, Luis de; 289.

Suárez, Esteban; 411. 
T

Taboada, Lope de; 212, 389.

Torquemada, Juan de; 152.

Torres, Álvaro de; 50, 84, 189, 335, 357.

Troche, Diego; 156, 320, 338.

$\mathbf{U}$

Ulloa, Sancho de; 181, 396, 401, 412.

V

Valderas, Álvaro de; 332, 354.

Valderrábano, Diego de; 109, 167, 316, 340, 409

Valderrávano, Diego de, v. Valderrábano, Diego de.

Vallejo, Rodrigo de; 186.

Varela, Gavriel; 231.

Varela, Juan; 329.

Vázquez, Álvaro; 307.

Vázquez de Bustelo, Juan, v. Vázquez de
Bustelos, Juan.

Vázquez de Bustelos, Juan; 204, 380.

Vázquez de Caboarcos, Alonso; 198, 374.

Vázquez de Cavarcos, Alonso, v. Vázquez de Caboarcos, Alonso.

Vega, Fernando de, v. Vega, Hernando de.

Vega, Hernando de; 262, 263 (nota 32), 265 (nota 33), 266, 282, 297.

Villalón, Alonso de; 119, 230.

Villamarín, Luis de; 210, 390.

Villandrando, Pedro de; 397,402.

Villareal, Fernando de; 126.

Villarroel, Luis de; 318, 342.

Villaseñor, Álvaro de; 179.

Villasur, Álvaro (o Alonso) de; 21, 47, 327, 350.

Vizcaíno, Ruy; 398.

$\mathbf{Y}$

Yáñez de Barraca, Pedro; 231.

\section{ÍNDICE DE LUGARES}

\section{A}

Agostín, Tierra de; 216.

Allariz, (Alariz, Ourense); 175, 346.

Almería; 1 (Ordenanza real de 1491), 125.

Altamira; 168, 315, 339.

Arcos (Los); 180, 328, 351.

Arévalo; 118.

Ávila; 116.

\section{B}

Baça, (Baza, Granada); 30, 61.

Bayona, (Baiona, Pontevedra);90, 257.

Benianço, (Vimianzo, A Coruña); 169, 317, 341.

Benienço, v. Benianço.

Betanzos,

Ciudad de; 117, 267, 367, 368, 369,

Provincia de; 2 (Cuenta de la quinta prorrogación), 26, 143, 147, 246, 253, 278, 292, 299, 308, 394

Bietar; 248.

Bollo, (Bolo, Ourense); 26, 28, 125, 254.

Bretaña; 34, 53.

Bullo, v. Bollo.
Buniato, v. Benianço.

Burgos; 125.

Burol, v. Burón.

Burón, (A Fonsagrada, Lugo); 23, 186, 333, 355.

C

Caldelas, (Castro Caldelas, Ourense); 114, 228.

Canba, Tierra de; 212.

Castilla; 29, 58, 121.

Castro de Covadoso, (O Carballiño, Ourense); 173, 321, 408.

Castro de Covdeso, v. Castro de Covadoso.

Castro de Oro, (Alfoz, Lugo); 23, 50, 84, 240, 263, 335, 357.

Castro de Rey, (Castro de Rei, Lugo); 22, 187, 201, 334, 356, 377, 378.

Castro del Rey, v. Castro de Rey.

Castro d'Oro, v. Castro de Oro.

Castro Doro, v. Castro de Oro.

Castrodoro, v. Castro de Oro.

Cebrero, Santa María del, (Pedrafita do Cebreiro, Lugo); 26, 28.

Çedera, (Cedeira, A Coruña); 370. 
Çervantes, v. Cervantes.

Cervantes, (Cervantes, Lugo); 184, 185, 332, 354.

Çernades; 23.

Corel, (Courel, Lugo); 177, 325, 348.

Coruña, La,

Ciudad de; 194, 242, 267, 298, 299, 308, 365 , 393 ,

Monasterio de Santo Domingo de; 248,

Provincia de; 10, 2 (Cuenta de la quinta prorrogación), 26, 27, 28, 143, 147, 246, 253, 278, 292, 394.

Coviel, v. Corel.

\section{F}

Forelos; 152,

\section{G}

Galicia,

Hermandad de; 1 (Ordenanza real de 1491), 2 (Cuenta de la quinta prorrogación), 29, 30, 125, 3 (Hermandad de Galicia. Sexta prorrogación), 3. (nota 31), 4 (Gastos de la Hermandad de Galicia. Sexta prorrogación), 251, 6 (Hermandad de Galicia. Séptima prorrogación), 274.

Reino de; 1 (Ordenanza real de 1491), 3, 5, $23,24,29,31,34,44,48,49,51,52,59$, $60,82,96,98,99,107,108,122,125,126$, $127,130,132,139,4$ (Gastos de la Hermandad de Galicia. Sexta prorrogación), 231, 5 (Repartimiento de peones), 252, 268, 272, 276, 283.

Galizia, v. Galicia.

Granada; $102,116,120,265$. (nota 33).

\section{H}

Herrera, v. Herrera del Negral.

Herrera del Negral, (Guntín, Lugo); 204, 380.

Herreros; 406.

$\mathbf{J}$

Jaén; 96, 132.

$\mathbf{L}$

Loolla; 249.

Lorenzana, (Lourenzá, Lugo); 376.
Lugo,

Ciudad de; 59, 62 , 91, 203, 205, 218, 330, $352,379,381$.

Fortaleza de; 89, 182.

Hermandad de; 56 .

Obispo de; 89, 182.

Provincia de; 10, 2 (Cuenta de la quinta prorrogación), 26, 27, 28, 57, 143, 149, 253, 280, 294, 304

\section{$\mathbf{M}$}

Moechen, (Moeche, A Coruña); 114.

Moechin, v. Moechen

Mondoñedo,

Ciudad de; 23, 188, 197, 359.

Hermandad de; 301 .

Obispado de; 198.

Provincia de; 10, 2 (Cuenta de la quinta prorrogación), 26, 27, 28, 143, 148, 253, 279, 293, 301

Monforte, v. Monforte de Lemos.

Monforte de Lemos; 114, 178, 326, 349.

Montedoro; 398.

Monte Sacro, (Boqueixón, A Coruña); 109, 167, $340,409$.

Monte Sagro, v. Monte Sacro.

Montesagro, v. Monte Sacro.

Muros (Muros, A Coruña); 231.

\section{$\mathbf{N}$}

Navares, (Los), v. Novaes.

Novaes, (Los), (Quiroga, Lugo); 176, 324, 347.

Novays, v. Novaes.

Noya, (Noia, A Coruña); 363.

\section{$\mathbf{O}$}

Orense,

Ciudad de; 412.

Iglesia de; 23, 174, 322, 345 .

Provincia de; 10, 2 (Cuenta de la quinta prorrogación), 26, 27, 28, 125, 143, 150, 211, 253, 254, 281, 295, 303.

$\mathbf{P}$

Pallares, (Guntín, Lugo); 204, 214, 387.

Panbre, (Palas de Rei, Lugo); 181, 329.

Peñaflor, (Pontevedra); 85, 171, 319, 343. 
Pynelas, (Las); 377.

Ponferrada, (Ponferrada, León); 57, 119, 229, 237.

Portugal; 244.

Puebla de Neyra, (La), (Láncara, Lugo); 207, 382.

Puertomarín, (Portomarín, Lugo); 215, 386.

Puerto Marín, v. Puertomarín.

\section{Q}

Quiroga, (Quiroga, Lugo); 347.

\section{$\mathbf{R}$}

Riango, (Rianxo, A Coruña); 170, 318, 342.

Rianjo, v. Riango.

Ribera de Aguera; 56.

Roma; 112.

\section{$\mathbf{S}$}

San Martín de Mondoñedo, (Foz, Lugo).

Coto de; 196, 372.

Monasterio de; 26, 28, 254.

Santiago,

Arzobispado; 27, 406

Ciudad de; 26, 28, 192, 193, 221, 231, 254 . $360,361,362,403$

Iglesia de; 26, 28.

Provincia de; 10, 2 (Cuenta de la quinta prorrogación), 26, 28, 140, 143, 246, 253 , 277, 291.

Sant Martino de Mondoñedo, v. San Martín de Mondoñedo.

Sarria, (Lugo),

Fortaleza de; 47, 179, 241.

Villa de; 21, 26, 28, 47, 113, 179, 208, 209 , 233, 254, 327, 350, 383.

Seçilia; 252.

Segovia; 4, 134.

Sevilla; 55 .
Soboroso, v. Sobroso

Sobroso, (Mondariz, Pontevedra); 227, 232, 323, 392.

Sotomayor, (Soutomaior, Pontevedra); 46, 172, $320,338$.

T

Toral; 113.

Torés; 183, 331, 353.

Torres, (Lugo); 56, 92.

Tuy,

Obispado de; 26, 27, 253.

V

Val de Armeo; 206.

Val de Lorençana, v. Val de Lorenzana.

، Val de Lorenzana, (Lourenzá, Lugo); 199, 200 375

Vayona, v. Bayona.

Villa Juan, v. Villajuan.

Villajuan, (Cospeito, Lugo); 23, 190, 336

Villalba, (Vilalba, Lugo); 45,191, 358, 394.

Villalón; 119.

Villalva, v. Villalba.

Villamarín, (Vilamarín, Ourense); 390.

Villamayor, v. Mondoñedo.

Villamayor de Mondoñedo, v. Mondoñedo.

Villa Mayor de Mondoñedo, v. Mondoñedo.

Vivero, (Viveiro, Lugo); 195, 371.

Vizcaya; 230, 243.

$\mathbf{Y}$

Yndias; 231

$\mathbf{Z}$

Zebrero, Santa María de, v. Cebrero, Santa María del. 